\title{
43. PLEISTOCENE FANGLOMERATE DEPOSITION RELATED TO UPLIFT OF THE TROODOS OPHIOLITE, CYPRUS ${ }^{1}$
}

\author{
Andrew Poole ${ }^{2}$ and Alastair Robertson ${ }^{3}$
}

\begin{abstract}
The Pleistocene Fanglomerate Group of the southern part of Cyprus exemplifies coarse alluvial clastic deposition within a zone of focused tectonic uplift, related to collision of African and Eurasian plates, as documented by Ocean Drilling Program Leg 160. During the Pleistocene, the Troodos ophiolite was progressively unroofed, resulting in a near-radial pattern of coarse clastic sedimentation. The Pleistocene Fanglomerate Group depositionally overlies Pliocene marine sediments. Along the southern margin of the Troodos Massif the contact is erosional, whereas along its northern margin a regressive fan-delta (Kakkaristra Fm.) intervenes.

The Pleistocene Fanglomerate Group is subdivided into four units (termed F1-F4), each of which were formed at progressively lower topographic levels. A wide variety of alluvial units are recognized within these, representing mainly high-energy coarse alluvial fans, channel fans, braidstream, and floodplain environments. A near-radial sediment dispersal pattern away from Mt. Olympos is indicated by paleocurrent studies, based on clast imbrication.

Provenance studies indicate relatively early unroofing of the ophiolite, but with only minor localized erosion of ultramafic rocks from the Mt. Olympos area. Clasts of erosionally resistant lithologies, notably ophiolitic diabase and Miocene reefrelated limestone, are volumetrically over-represented, relative to friable basalt and early Tertiary pelagic carbonate sediments.

The younger Fanglomerate Group units (F3 and F4) can be correlated with littoral marine terraces previously dated radiometrically at about 185-219 ka and 116-134 ka, respectively. However, the earlier (F1 and F2) Fanglomerate Group units can, at present, be dated only as early to middle Pleistocene.

The principle variables that affected deposition of the Pleistocene Fanglomerate Group as a whole are tectonic uplift isostatic effects, glacio-eustatic sea-level change, short- and long-term climatic change, and lithology. However, the dominant control was tectonic uplift that apparently peaked during early and middle Pleistocene time. Aggradation of fluvial sediments (F1 and F2) took place at times of relative sea-level high with associated terrace formation. This was followed by downcutting during periods of relative sea-level fall when surface uplift continued.

The dominant control on the younger (F3 and F4) units was glacio-eustatic sea-level change, during a time when littoral marine sediments accumulated, and rates of surface uplift may have decreased. Finally, the Holocene alluvial deposition was also affected by anthropogenic effects, notably deforestation.
\end{abstract}

\section{INTRODUCTION}

This paper is concerned with the Pleistocene clastic sedimentation in Cyprus, located to the north of Sites 965-968 drilled during Ocean Drilling Project Leg 160 (Emeis, Robertson, Richter, et al., 1996, Fig. 1). Coarse-grained, non-marine sediments dominate the Pleistocene successions of the southern part of Cyprus. These sediments are exposed around the periphery of the Troodos ophiolitic massif, and are also associated with a small neotectonic graben structure in western Cyprus. Recent studies of coarse alluvial deposition have particularly focused on extensional faulting and graben development (e.g., Leeder, 1993; Postma and Drinia, 1993; Collier et al., 1993), but here we focus on conglomerates shed radially from a rising point source. Previous studies of the Pleistocene of southern Cyprus, including evidence from shallow-marine and continental sediments and geomorphic erosion surfaces, have indicated that strong surface uplift of the Troodos ophiolite took place, beginning in the upper Pliocene (Robertson, 1977; McCallum and Robertson, 1990; Houghton et al., 1990; Poole and Robertson, 1991). The results of Leg 160, following geophysical surveys (Limonov et al., 1994; Robertson et al., 1995a), suggest that the overall driving force of the uplift of the Troodos ophiolite was the collision of a continental fragment, the Eratosthenes Sea-

${ }^{1}$ Robertson, A.H.F., Emeis, K.-C., Richter, C., and Camerlenghi, A. (Eds.), 1998. Proc. ODP, Sci. Results, 160: College Station, TX (Ocean Drilling Program).

${ }^{2}$ CEFAS, Lowestoft Laboratory Pakefield Road, Lowestoft, Suffolk, NR33 OHT, United Kingdom.

${ }^{3}$ Department of Geology and Geophysics, University of Edinburgh, West Mains Road, Edinburgh EH9 3JW, United Kingdom. Alastair.Robertson@glg.ed.ac.uk mount, with the active boundary of the Eurasian and African plates (i.e., the Cyprus active margin) located directly south of Cyprus (Robertson et al., 1995a, b; Emeis, Robertson, Richter, et al., 1996; Fig. 1). Related to this collision, the ultramafic core of the Troodos ophiolite underwent diapiric protrusion, causing strong surface uplift focused on Mt. Olympos. The uplift resulted in shedding of large volumes of coarse clastic sediments that accumulated as relatively thin, alluvial deposits onshore, and also as much thicker turbidite deposits offshore in a trench located between southern Cyprus and the Eratosthenes Seamount. Clastic deposition continued into the late Holocene when anthropogenic influences came into play.

In this paper, we will describe and interpret the Pleistocene-Holocene coarse fluvial sediments and evaluate the relative roles of tectonic uplift vs. glacio-eustatic sea-level change and climatic effects in their formation.

\section{REGIONAL SETTING}

The coarse Pleistocene-Holocene sediments of southern Cyprus, here termed the Fanglomerate Group (Poole, 1992), form the highest stratigraphic levels of the sedimentary cover of the Upper Cretaceous Troodos ophiolite (Fig. 2). The ophiolite comprises a complete suite of intrusive (ultramafics gabbro, diabase) and extrusive (basalt) lithologies. It is overlain by a Late Cretaceous to Miocene, predominantly deep-water, pelagic carbonate succession (Lefkara Formation), deep to shallow-marine sequences (Pakhna Formation; Robertson, 1976; Eaton and Robertson, 1993). Pliocene deposition was ini- 
Figure 1. Outline map of the Eastern Mediterranean showing the location of Cyprus and nearby sites drilled during Leg 160. Inset: plate boundaries of Mediterranean region.
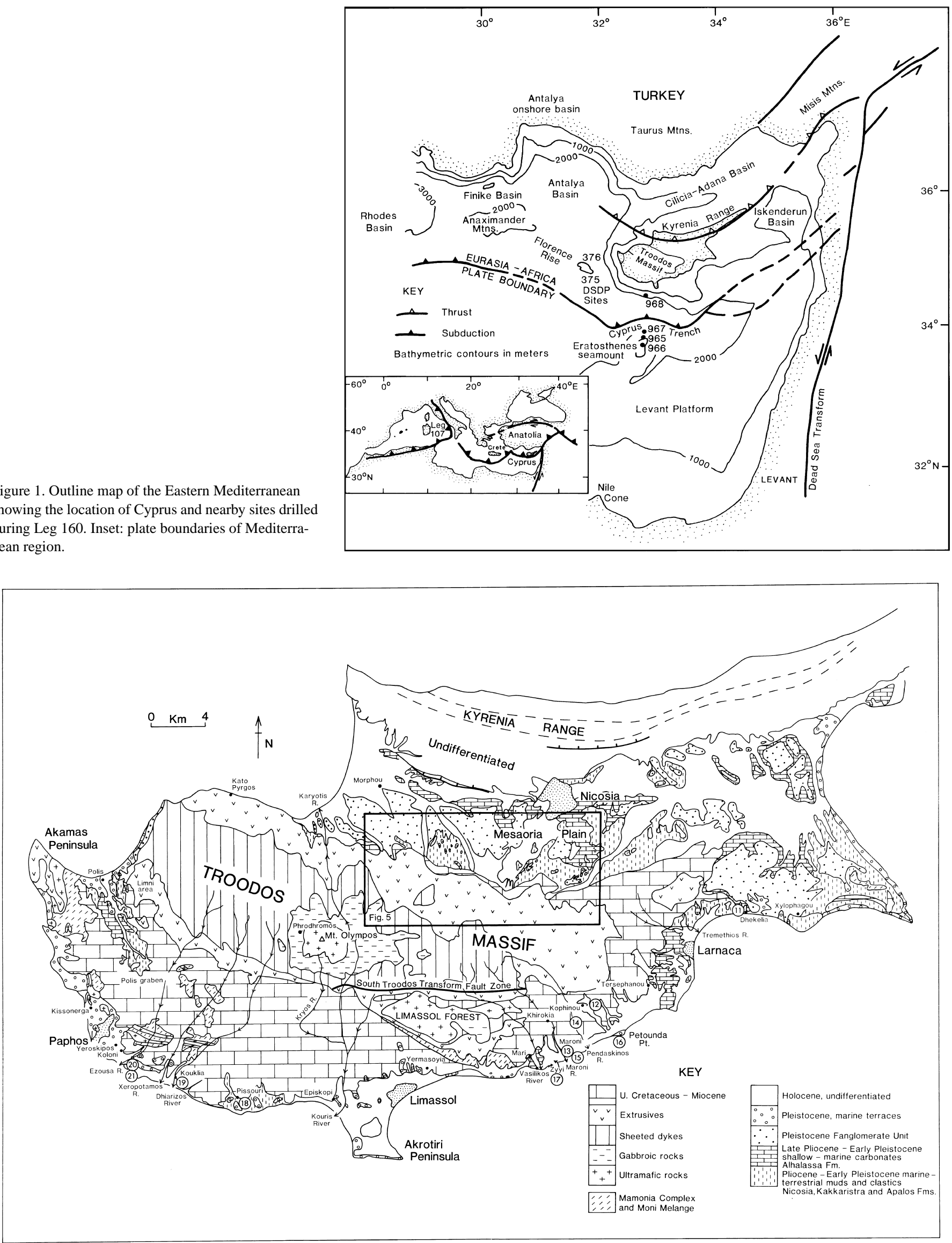

Figure 2. Outline map of Cyprus showing the distribution of the Pleistocene units discussed in this paper. Inset is detailed in Figure 5. 
tially fine-grained marine (Nicosia Formation), then shallow-marine (Kakkaristra Formation), to fluvial (Apalos Formation) in the upper Pliocene (McCallum, 1989; McCallum and Robertson, 1990, 1995a; Table 1). Shallow-marine carbonates of late Pliocene to early Pleistocene age (Athalassa Formation) are present in some areas (McCallum and Robertson, 1995b). A shallowing-upward succession of late Pliocene age records an early stage of surface uplift of the Troodos ophiolite. However, the Pleistocene Fanglomerate Group, discussed here, is much more widespread than the underlying Pliocene conglomerates and is related to greater surface uplift, which is focused on Mt. Olympos in the center of the Troodos ophiolite during Pleistocene time (Robertson, 1990; Poole and Robertson, 1991). Mt. Olympos dominates the present-day drainage pattern as shown in Figure 3.

\section{PREVIOUS WORK AND NOMENCLATURE}

The coarse-grained clastic sediment unit of Pleistocene age was previously known as the Fanglomerate Series. Bellamy and JukesBrown (1905) and Cowper-Reed (1930) were the first to describe alluvial sediments on the Mesaoria Plain. Henson et al. (1949) outlined the distribution of these sediments in the foothills of the Troodos Massif, in the Kyrenia Range and on the Mesaoria Plain. The term Troodos Massif is used here to include both the uplifted Troodos ophiolite and its overlying sedimentary cover. The Cyprus Geological Survey Department mapped the Fanglomerate sediments on the northern flanks of the Troodos Massif and on the Mesaoria Plain (Bear, 1960; Gass, 1960; Carr and Bear, 1960). Ducloz (1965) correlated "Fanglomerate age" terraces with the Pleistocene glacial chronology and Mediterranean marine stages, that were then recognized. McCallum (1989) subsequently proposed the first detailed model for deposition of the Fanglomerate Group to the north of the Troodos massif. Valleys were incised and subsequently infilled with conglomerates newly derived from the Troodos massif, and thin sheets of sediment spread out onto the Mesaoria Plain. Subsequent incision resulted in the formation of terraces.
Studies of the Fanglomerate Group on the southern margin of the Troodos Massif were limited to brief descriptions in the memoirs of the Geological Survey Department (e.g., Bear and Morel, 1960). Bagnall (1960) recognized three river terraces in the Larnaca area and correlated these with coastal marine units. Terraces were recognized at 80-100 feet, 25-35 feet, and 10-20 feet above the valley floor. Pantazis (1967) identified a "Higher River Terrace" and "Alluvium." Correlations between the lower Vasilikos Valley and other areas of Cyprus were established by Gomez (1987), who identified four phases of Fanglomerate Group deposition. In addition, Stevens and Wedel (1992) recently studied local aspects of Quaternary alluvial fans in southeastern Cyprus with the aim of identifying cyclic tendencies that could relate to modern geomorphological features and processes.

\section{Local Setting}

Based on an integrated study of the sedimentology, geomorphology, and tectonic setting of the Pleistocene of southern Cyprus, it was established that major erosional horizons could be correlated throughout southern Cyprus (Poole, 1992; Poole and Robertson, 1991). In places, these erosion surfaces are overlain by coarse conglomerates and other sediments (caliche, paleosols) of the Fanglomerate Group. In both southeastern and northwestern Cyprus, alluvial clastic sediments can be traced into shallow-marine deltaic facies and the correlated with littoral carbonates. These carbonates contain cor-

Table 1. Stratigraphy of the Fanglomerate Group in relation to underlying units.

\begin{tabular}{cccc}
\hline $\begin{array}{c}\text { Age } \\
\text { (Ma) }\end{array}$ & Period & \multicolumn{1}{c}{ Stratigraphy } & \multicolumn{1}{c}{ Lithology } \\
\hline 2.0 & Pleistocene & Fanglomerate Group & $\begin{array}{c}\text { Conglomerates and } \\
\text { sandstones }\end{array}$ \\
5.2 & Pliocene & $\begin{array}{l}\text { Apalos Formation } \\
\text { Kakkaristra Formation } \\
\text { Athalassa Formation }\end{array}$ & $\begin{array}{c}\text { Calcarenites, } \\
\text { sandstones, and } \\
\text { conglomerates } \\
\text { Marls, silts, muds, } \\
\text { sandstones, and } \\
\text { conglomerates }\end{array}$ \\
& & Nicosia Formation & \\
& & \\
\end{tabular}

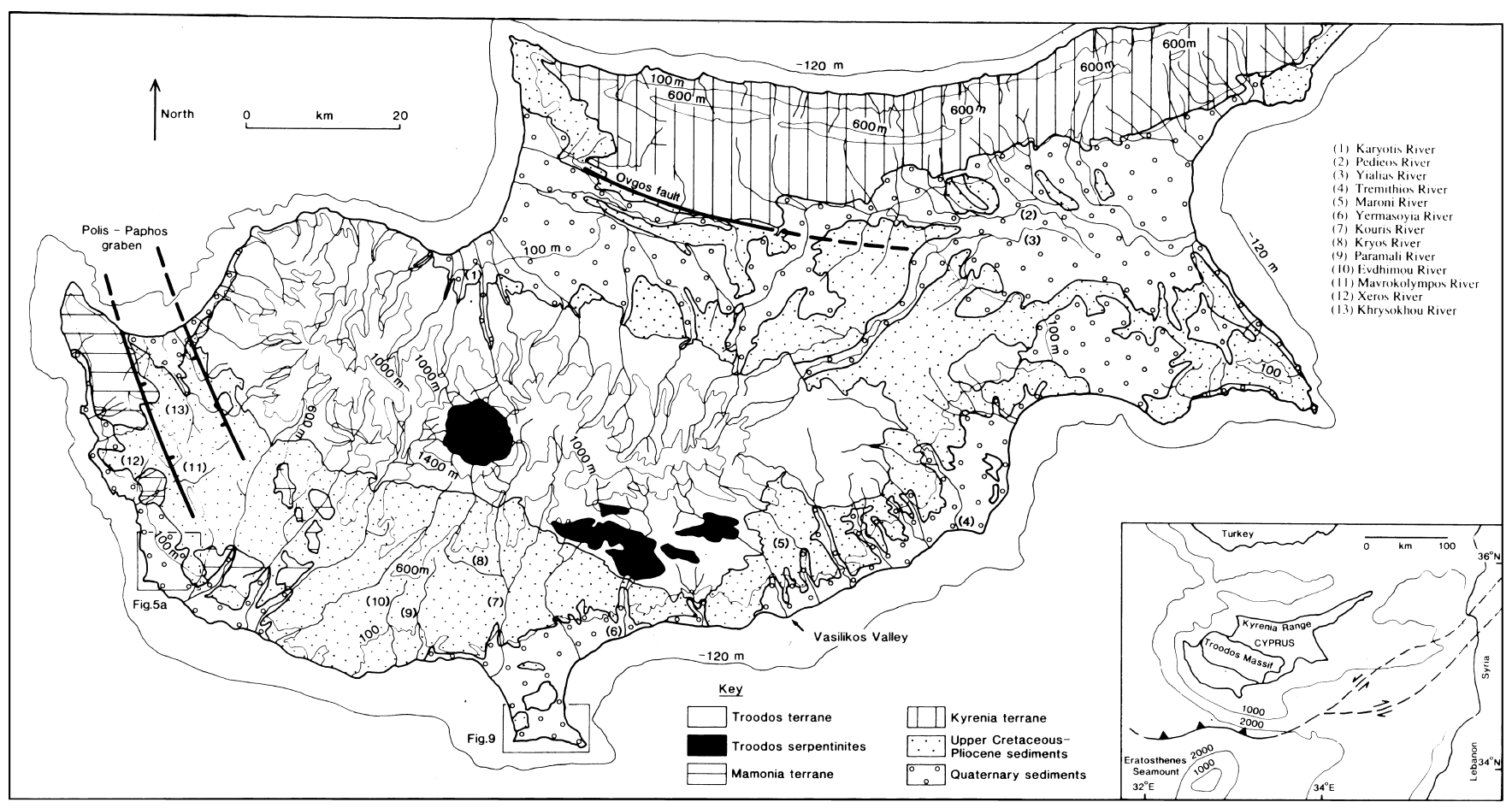

Figure 3. Present-day drainage of southern Cyprus. 
als (Cladochora caespitosa) that have been dated radiometrically using the Uranium-series technique (Poole et al., 1990). The main littoral deposits associated with individual erosion surfaces are broadly contemporaneous throughout southern Cyprus. Four main erosion surfaces are recognized and named F1 (oldest) to F4 (youngest), as shown in Figure 4. The F1 terrace locally overlies shallow-marine to alluvial sediments of upper Pliocene to early Pleistocene age on the Mesaoria Plain and in southern and southwestern Cyprus (McCallum, 1989; McCallum and Robertson, 1995a, b). The successive (F1 to F4) erosion surfaces are associated with individual coarse clastic units of the Fanglomerate Group discussed here. The F1 Unit is dated as early to mid-Pleistocene; the F2 Fanglomerate Unit is also of early to middle Pleistocene age; the F3 and F4 units are of late Pleistocene age (i.e., 185-219 ka and 116-141 ka, respectively). The ages of the F1 and F2 Fanglomerates are not well constrained, as correlative marine terraces do not contain coral or other dateable material.

Earlier studies have indicated that the Troodos Massif experienced strong focused uplift in late Pliocene-mid-Pleistocene, with less intense uplift continuing into late Pleistocene time (116-141 ka) (McCallum and Robertson, 1990; Houghton et al., 1990). Marine terraces were deposited during times of relative sea-level high allowing accumulation of littoral carbonate that is locally rich in coral. Terrestrial terraces inland developed by fluvial processes, mainly during

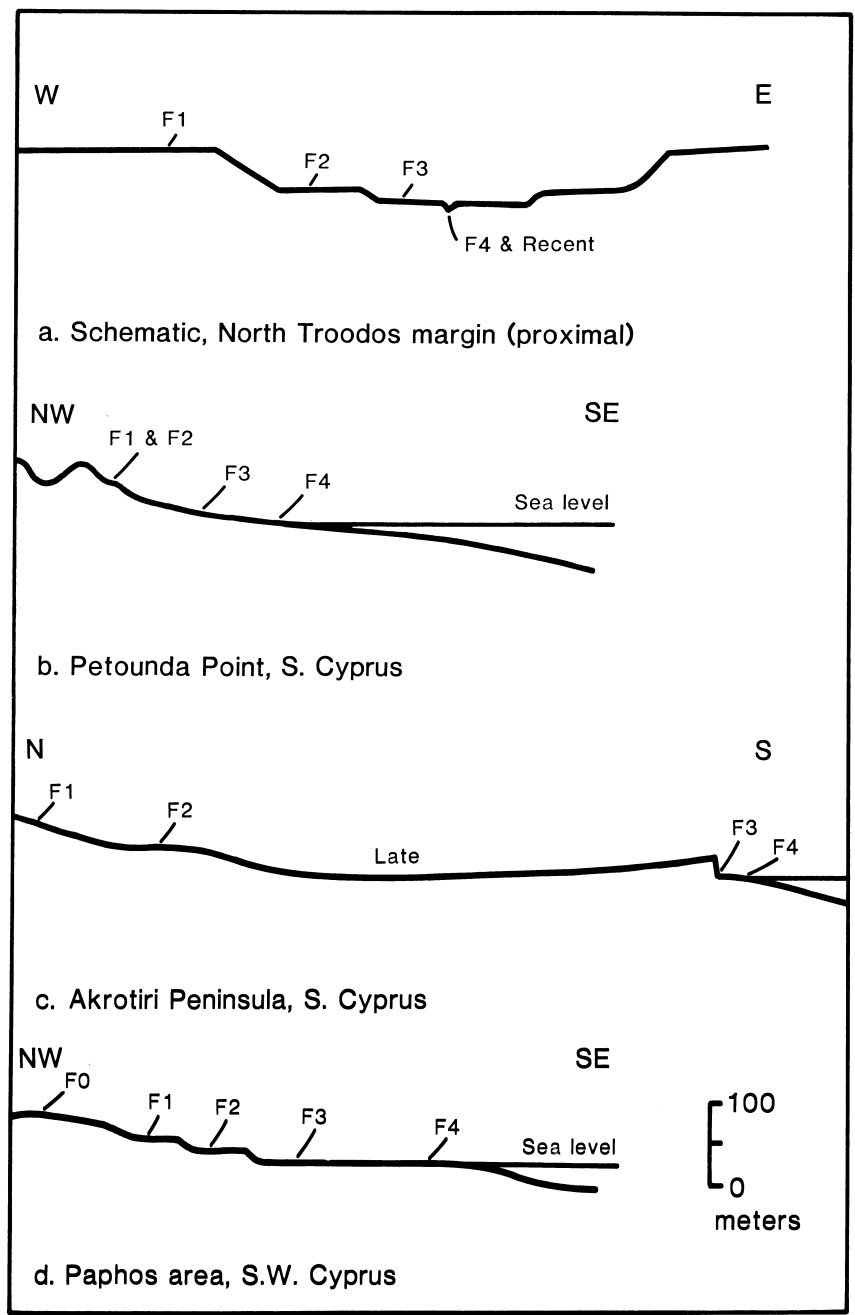

Figure 4. Selected topographic profiles for coastal southern Cyprus, showing the relative positions of the F1-F4 units. A. North Troodos margin (schematic); B. Petounda Point, south Cyprus; C. Akrotiri Peninsula, south Cyprus; D. Paphos area, southwest Cyprus. times of relative sea-level high, associated with sediment aggradation. After about $116 \mathrm{ka}$, emergence of coastal areas was restricted to a maximum of about $6 \mathrm{~m}$. During the upper Pleistocene the dominant control was glacio-eustatic sea-level change, especially the highstand (at about 116-141 ka) that correlates with oxygen isotope Substage 5e (Poole and Robertson, 1991).

The surface outcrop of the Fanglomerate Group gives little indication of its true thickness. In southeast Cyprus it is only a few meters thick, and on the north Troodos margin it is $<90 \mathrm{~m}$ thick (Zomenis, 1977), or <12 m thick (McCallum, 1989). Borehole data show that the thickness is up to $86 \mathrm{~m}$, but this varies greatly around the Troodos margin. Exposures and borehole data in southeastern Cyprus indicate that the Fanglomerate Group consists of a thin capping unit north of Xylophagou, whereas thicker, more extensive, exposures occur in coastal areas in the east (Akrotiri Peninsula) and south (Dhekelia area). In the southwest, the Fanglomerate Group is patchy, and sequences are mainly $<5 \mathrm{~m}$ thick. Further north in the Polis Graben, extensive exposures of the Fanglomerate Group rarely exceed an exposed thickness of 10-15 m (Payne, 1996).

\section{SEDIMENTARY FACIES AND DEPOSITION PROCESSES}

Differences in facies occur in various geographical areas of southern Cyprus that will be discussed in the following order: (1) North margin of the Troodos Massif; (2) Southeastern Cyprus; (3) Southern Cyprus; (4) Southwestern Cyprus; and (5) Polis Bay area. Most emphasis is placed on the north Troodos margin as the exposures are more extensive there. Locations are listed in Table 2.

\section{Northern Troodos Margin}

The Fanglomerate Group (Fig. 5) oversteps progressively older units of the Troodos Massif down to the Troodos ophiolite at the southern and western extent of the exposure. Thicknesses of the Fanglomerate Group, based on borehole data, are shown in Figure 6. Four units are distinguished, based on height above sea level, as follows:

Table 2. Details of locations of sedimentary logs.

\begin{tabular}{|c|c|c|}
\hline $\begin{array}{c}\text { Location } \\
\text { number }\end{array}$ & Grid reference & Location \\
\hline $1-7$ & $(162,775)$ Sh.11 & Malounda \\
\hline $1-19$ & $(017,810)$ Sh.11 & Vyzekia \\
\hline $1-58$ & $(013,800)$ Sh.11 & Astromeritis \\
\hline $1-68$ & $(995,859)$ Sh. 10 & Astromeritis \\
\hline $1-72$ & $(973,842)$ Sh. 10 & Kato Koutraphas \\
\hline $1-73$ & $(985,842)$ Sh. 10 & Kato Koutraphas \\
\hline $1-79$ & $(167,797)$ Sh.11 & Ayios Ioannis \\
\hline $1-83$ & $(167,797)$ Sh. 11 & Aredhiou \\
\hline $1-84$ & $(077,843)$ Sh.11 & Orounda \\
\hline $1-86$ & $(074,797)$ Sh.11 & Kato Moni \\
\hline $1-89$ & $(078,844)$ Sh.11 & Orounda \\
\hline $1-93$ & $(202,786)$ Sh.11 & Peratis Hill \\
\hline $1-94$ & $(195,762)$ Sh. 11 & Politiko \\
\hline $1-96$ & $(193,770)$ Sh.11 & Peratis Hill \\
\hline $1-109$ & $(015,816)$ Sh. 11 & Potami \\
\hline $1-156$ & $(39,55)$ Sh. 20 & Menoyia \\
\hline $1-160$ & $(354,497)$ Sh. 20 & Ayios Theodhores \\
\hline $1-165$ & $(318,476)$ Sh. 24 & Maroni \\
\hline $2-41$ & $(520,443)$ Sh. 22 & Akhelia \\
\hline $2-45$ & $(531,452)$ Sh. 22 & Akhelia \\
\hline $2-54$ & $(620,415)$ Sh.22 & Kouklia \\
\hline $2-83$ & $(660,7350)$ Sh. 21 & Dhekelia \\
\hline $3-10$ & $(480,503)$ Sh. 21 & Petounda Point \\
\hline $3-19$ & $(313,432)$ Sh. 24 & Zyyi \\
\hline $3-30$ & $(755,352)$ Sh. 22 & Pissouri \\
\hline M5 & $(325,451)$ Sh. 20 & Maroni \\
\hline
\end{tabular}

Note: Grid references and 1:50,000 ordinance survey sheet number of locations documented in the text. Details of locations from Poole (1990). 


\section{F1 and F2 Fanglomerate Units (Lower-Middle Pleistocene).}

The F1 and F2 Fanglomerate Group units, equivalent to the Kantara and Kambia Gravels of Ducloz (1965), are described together here, in view of their similar sedimentary facies (Fig. 7). The F1 Fanglomerate unit is heavily dissected throughout the Mesaoria Plain. The F2 Fanglomerate unit is widely exposed in the western Mesaoria Plain and, like the F1 Fanglomerate unit, is strongly eroded in the eastern part of the plain. Both Fanglomerate units are overlain by red terra rossa-type paleosols and caliche horizons. Photographs are shown in Figures 8 and 9.

\section{Proximal Areas}

Proximal facies have been largely eroded, but remnants crop out up to $1 \mathrm{~km}$ from the margin of the Troodos Massif. Proximal conglomerates of the F2 Fanglomerate unit ( $<15 \mathrm{~m}$ thick) unconformably overlie extrusives of the Troodos ophiolite in the center of the area (e.g., Vyzakia, Kato Moni, and Malounda). To the east and west they overlie Neogene sediments (e.g., Kato Koutraphas; see Fig. 6). Troodos lavas beneath the F2 Fanglomerate unit are weathered and commonly capped by a thin caliche (e.g., at Kato Moni and Malounda). Proximal units (i.e., at Vyzakia) are composed of red, unconsolidated, massive structureless and poorly sorted conglomerates. The basal contact with the lavas is uneven, with a relief of 3-4 m. Clasts within the proximal conglomerates are mainly $<80 \mathrm{~cm}$ in size, with occasional angular, "outsized" clasts.

The proximal sequences are dominated by coarse, massive, structureless, unconsolidated, matrix- to grain-supported conglomerates, with a dominantly sand and silt matrix. The matrix is locally fine conglomerate, whereas clasts are generally angular to subangular (Fig. 7, $\operatorname{logs} 1-3$, Figs. 8, 9).

There are two units within the coarse conglomerate facies. Both are coarse-grained and poorly sorted with clasts up to $2 \mathrm{~m}$ in diameter. A scoured contact is seen between the two conglomeratic units, with the development of caliche and sands such as that at Kato Moni and Vyzakia. The basal conglomerates are locally coarser grained than the upper units south of Kato Moni; elsewhere, coarser conglomerates are present in the upper conglomeratic units west of Kato
Moni and at Malounda. The basal units have a greater proportion of locally derived lava clasts and fewer diabase and gabbro clasts than the upper unit; also fewer reworked clasts are present.

\section{Intermediate Areas}

Intermediate areas, $1-5 \mathrm{~km}$ from the northern margin of the Troodos Massif, are dominated by coarse conglomerates (e.g., west of Akaki around Orounda and north of Malounda, Fig. 10) and contain igneous and minor sedimentary clasts such as gypsum and chalk that are $10-50 \mathrm{~cm}$ in size. The clasts are commonly polished, with a local caliche crust. Conglomerates are roughly bedded and locally graded, with fine conglomerates toward the top of some units (Fig. 7, logs 49). This intermediate unit is distinguished from proximal equivalents based on lateral variation, including thin lenses of fine conglomerate and sand.

\section{Distal Areas}

The F1 Fanglomerate unit is not found in distal locations on the northern Troodos margin. However, the F2 Fanglomerate unit crops out in distal localities $>5 \mathrm{~km}$ from the north Troodos margin (e.g., on the main Troodos road between Akaki and Astromeritis; Fig. 11).

In distal locations, the F2 Fanglomerate forms well-bedded, poorly cemented channelized gravels and sands, with cross-stratification, small fining-up sequences, silts, and caliche horizons. Sections 10 $\mathrm{km}$ north of the proximal F2 Fanglomerate unit exposures reveal cyclic, prograding foresets overlying massive, structureless conglomerate; caliche and silts cap individual cycles (Fig. 7, $\log 10$ ).

Channels are cut down into locally preserved F1 and F2 Fanglomerate unit sequences. Where best seen, sediments of the late Pliocene Apalos Formation are cut by the F1 Fanglomerate unit (i.e., at Kato Koutraphas; Fig. 5). Distal sequences of the F1 Fanglomerate unit were later incised by F2 Fanglomerate channels that were then filled with a coarse, immature, grain-supported lag overlain by finer grained matrix-supported conglomerates. A second coarse sediment unit, above an uneven, scoured contact comprises immature, massive, poorly bedded, coarse conglomerates, which cap many of the exposed F2 sedimentary sequences on the northern Troodos margin.

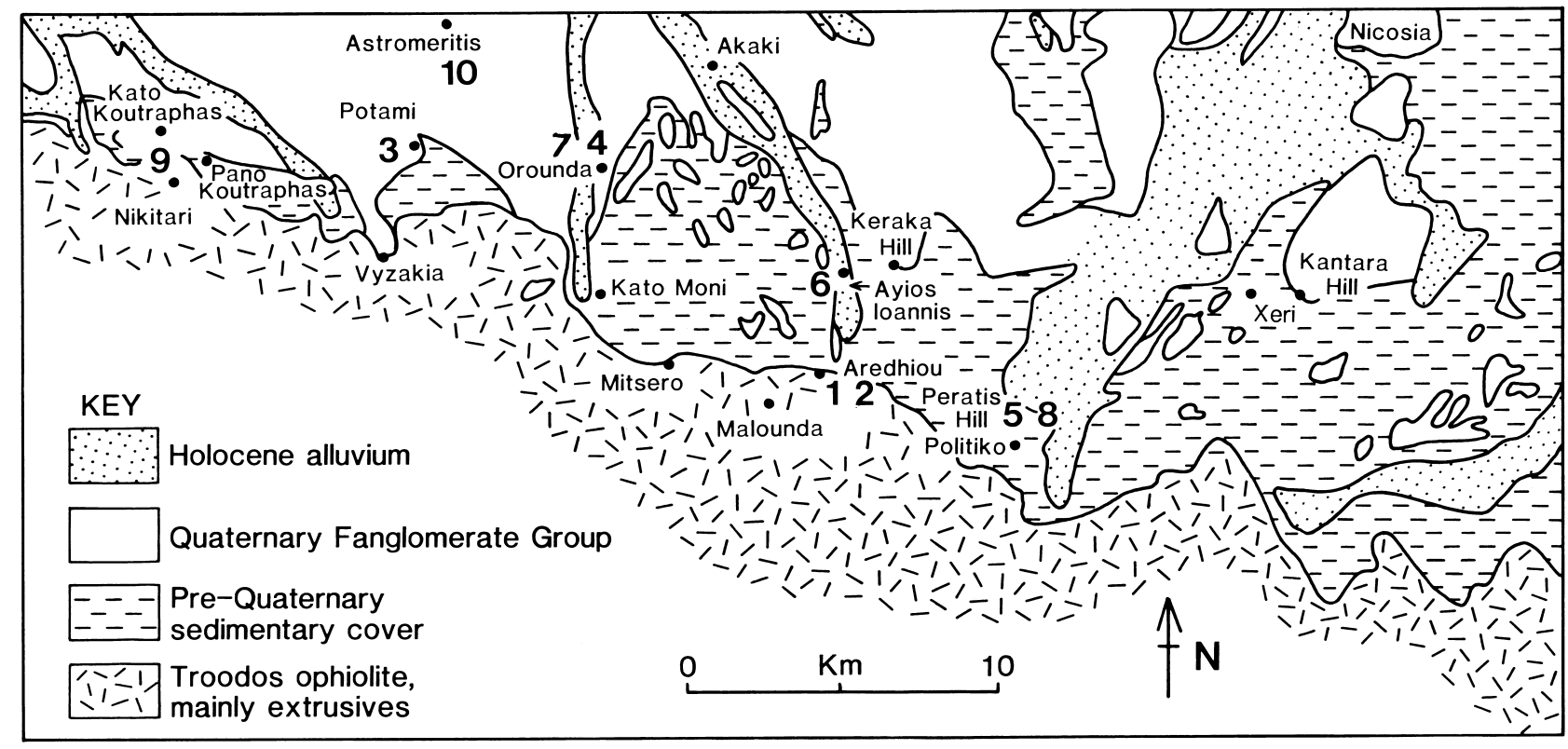

Figure 5. Simplified geological map of the northern margin of the Troodos Massif showing location of logs in Figure 7 and of places mentioned in the text. Detail of Figure 2 inset. 


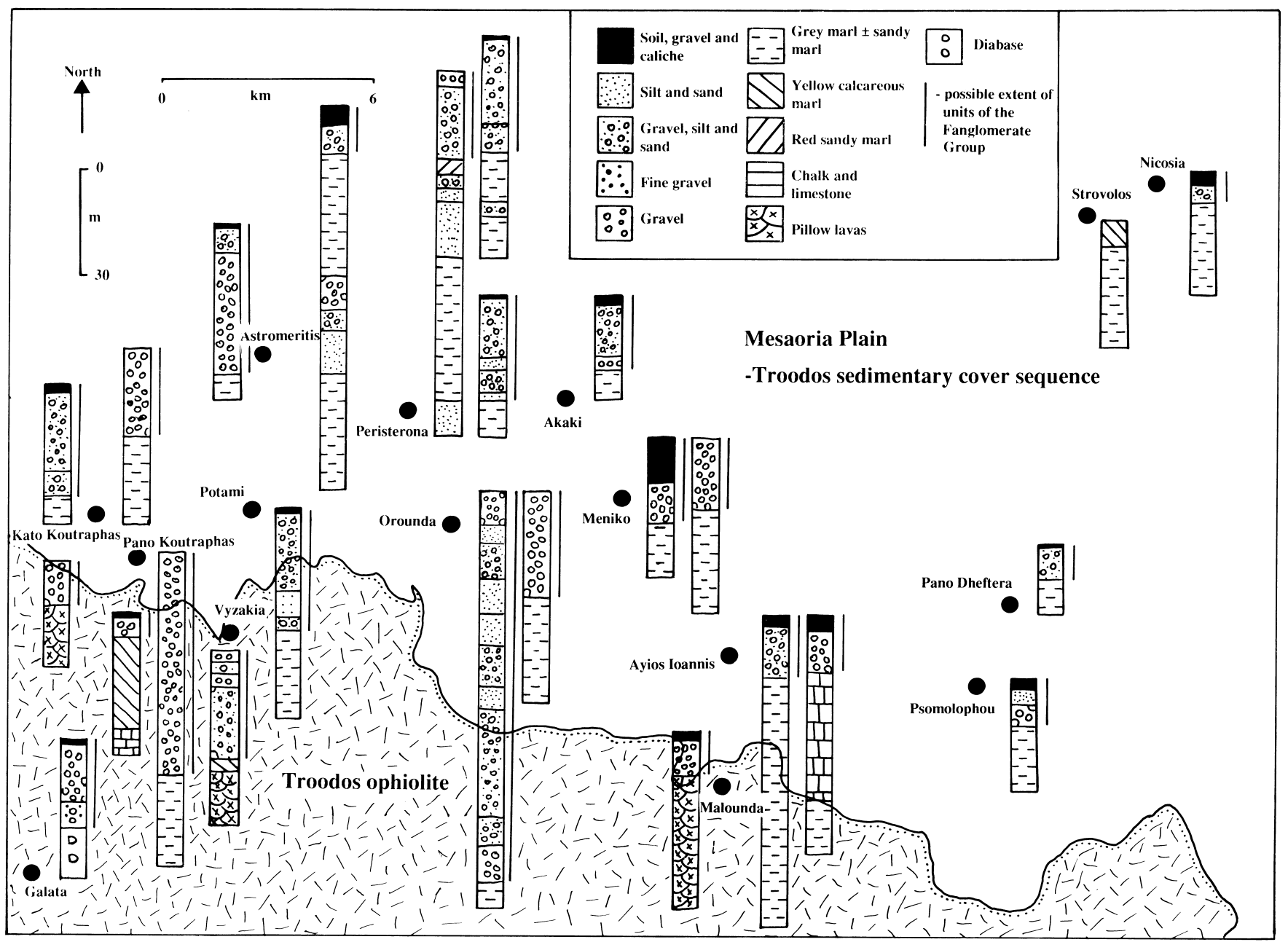

Figure 6. Borehole data showing the approximate thickness of the Fanglomerate Group along the northern Troodos margin. Vertical line marks probable extent of Pleistocene succession (note the distinction between Pleistocene and upper Pliocene conglomerate estimated based on available borehole records). Data derived from records provided by the Geological Survey Department, Cyprus.

\section{F3 Fanglomerate Unit (Early Late Pleistocene)}

In proximal areas close to the Troodos Massif, the F3 Fanglomerate unit comprises coarse conglomerates, similar to those at proximal locations in the F2 Fanglomerate unit. Sequences crop out at topographically lower levels than the F2 Fanglomerate unit and range in thickness from $<5 \mathrm{~m}$ (e.g., at Vyzakia), to about $10 \mathrm{~m}$ (e.g., north of Vyzakia; Fig. 5). The unit is dominated by massive, unsorted, ungraded, matrix- to grain-supported conglomerates, with pockets of well-sorted, grain-supported, medium-grade conglomerates and associated discontinuous pebble clusters. Toward the base, the sequence contains occasional large blocks of lava $<1 \mathrm{~m}$ in size.

The F3 proximal facies and associated erosion surfaces in the western Mesaoria Plain are commonly capped by caliche, together with clastic sediments eroded from the F2 Fanglomerate unit. These sediments form an alluvial deposit that commonly caps the coarse conglomerates of the F3 Fanglomerate unit (e.g., at Vyzakia; Fig. 5). These alluvial sediments are composed of mixed sands, fine-to-medium grain-supported gravels and discontinuous massive silty bands. Some of the silts were possibly derived from Pliocene silts beneath the F2 Fanglomerate unit.

\section{F4 Fanglomerate Units (Late Late Pleistocene)}

The F4 Fanglomerate crops out on the western Mesaoria Plain and forms distinctive units up to $3 \mathrm{~m}$ above present-day river channels. The sediments of the F4 Fanglomerate unit on the western and central
Mesaoria Plain areas are not as variable as those associated with the F2 and F3 Fanglomerate units. These sediments are predominantly coarse, poorly sorted, grain-supported conglomerates, similar to the coarse conglomerates of the F2 and F3 Fanglomerate units, although the F4 units have a greater proportion of grain-to-grain contacts. The clasts are predominantly rounded to subangular, locally up to $1 \mathrm{~m}$ in size (near Ayios Ioannis, Kato Moni, Kato Koutraphas area, and Potami; Fig. 5).

\section{Paleocurrent Data and Clast Analysis}

Paleocurrent data (i.e., clast imbrication and foreset orientation) were collected from the combined F1 and F2 units along the north Troodos margin (Fig. 12). They reveal a general swing in paleocurrents from northwest to northeast, moving from west to east across the Mesaoria Plain. This reflects radial drainage from Mt. Olympos as seen today (Fig. 3). However, in detail, adjacent coarse-grained units commonly show contrasting paleocurrent directions, reflecting local variations in channel orientations, for example where a channel has dissected a bar surface.

Clast analysis in the western and central Mesaoria Plain (Fig. 13) reveals the presence of a greater proportion of diabase and gabbro clasts in the Fanglomerate Group conglomerates than in the underlying Pliocene units that contain relatively more extrusive rocks (McCallum, 1989). By contrast, in the eastern portion of the Mesaoria Plain, the provenance of the Fanglomerate Group is similar to that of the underlying late Pliocene-early Pleistocene units in all areas of the north Troodos margin (i.e., dominated by extrusives and diabase). 


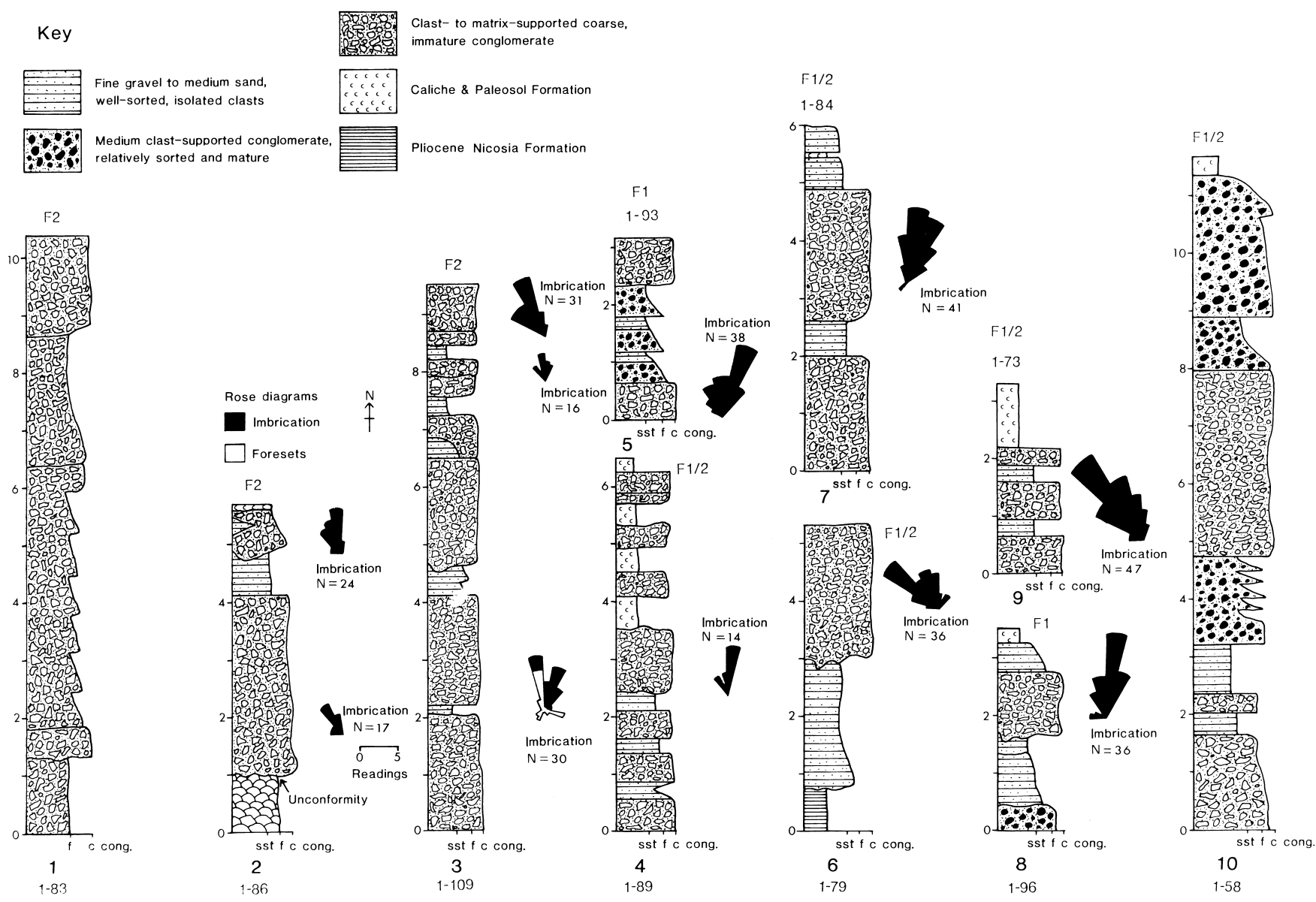

Figure 7. Facies of the Fanglomerate Group along the north Troodos margin. Logs 1-3 from proximal locations; $\operatorname{logs} 4-9$ from intermediate locations, and log 10 from distal location, relative to the Troodos ophiolite massif to the south. See Figure 5 and Table 2 for locations. F1 and F2 units are marked; F1/F2 indicates that the two unit have merged in intermediate areas, but are probably mainly F2.

Variation in clast type between the F1 and F2 Fanglomerate unit conglomerates is negligible. Ultramafic clasts are generally absent from the Fanglomerate Group, except very locally (i.e., close to the Karyotis River valley; Fig. 2). Ultramafic clasts were also reported from exposures of the Fanglomerate Group in the Morphou area in the northwest (Wilson, 1957), and Moore (1960) also noted gabbro and diabase clasts in this area.

The F4 Fanglomerate unit and also Holocene sediments in river courses of the western Mesaoria Plain include limestone sedimentary clasts of Miocene age. Igneous clasts are generally more mature than in the F1-F3 Fanglomerate units. Proportions of different igneous clasts vary locally. The presence of Miocene sedimentary clasts suggests that earlier Fanglomerate Group units must have been eroded to expose the underlying sedimentary sequences; thus, reworking of clasts has probably taken place from earlier Fanglomerate units into F4 and Holocene to present-day deposits.

The clast provenance data for the north Troodos margin indicate that major river channels drained the ultramafic core of the Troodos ophiolite during the Pleistocene, as in the present day. By contrast, clast types in both the Pliocene (McCallum, 1989) and Pleistocene sequences of the eastern Mesaoria Plain reflect transport by rivers that did not cut down into plutonic units of the Troodos ophiolite. These areas were further from the uplifted Troodos core and experienced less surface uplift during the Pleistocene, and thus less downcutting took place. An exception to this general pattern is the existence of such local topographic highs Kreatos Hill, near Mitsero, that continued to provide such sedimentary clasts as limestone to the Fanglomerate Group throughout the Pleistocene. Downcutting into the Pliocene and underlying sedimentary sequences took place later in the Pleistocene and resulted in an increased proportion of Neogene and Paleogene sedimentary clasts within the later F3 and F4 units of the Fanglomerate Group.

The Kyrenia Range to the north did not influence the Fanglomerate Group deposition on the south of the Mesaoria Plain, as clasts derived from the Kyrenia Range are absent from the Fanglomerate Group.

\section{Discussion}

Large-scale alluvial fan development took place on the northern Troodos margin during the early and middle Pleistocene (i.e., F1 and F2 times). The fans were fed by rivers draining the Troodos Massif. The F1 and F2 Fanglomerate units unconformably overlie ophiolitic lithologies on the western and central parts of the Mesaoria Plain, but are conformable on upper Pliocene sediments in the east. The simplest explanation is that contemporaneous uplift was more intense in the west, with erosion of the Troodos sedimentary cover during deposition of the Fanglomerate Group. Alternatively, the domal topography and drainage system of the Troodos Massif was developed in the upper Pliocene and then continued to control fluvial deposition during the Pleistocene in the eastern Mesaoria Plain. In the first interpretation, progressive unroofing of the Troodos Massif would be documented during the Pleistocene, whereas in the second, the radial dispersal pattern was established in upper Pliocene and need not have changed greatly during the Pleistocene even if uplift continued.

In an interpretation involving progressive surface uplift during the Pleistocene, increased proportions of clasts derived from generally lower stratigraphic levels, such as gabbro and ultramafics, would be 
A

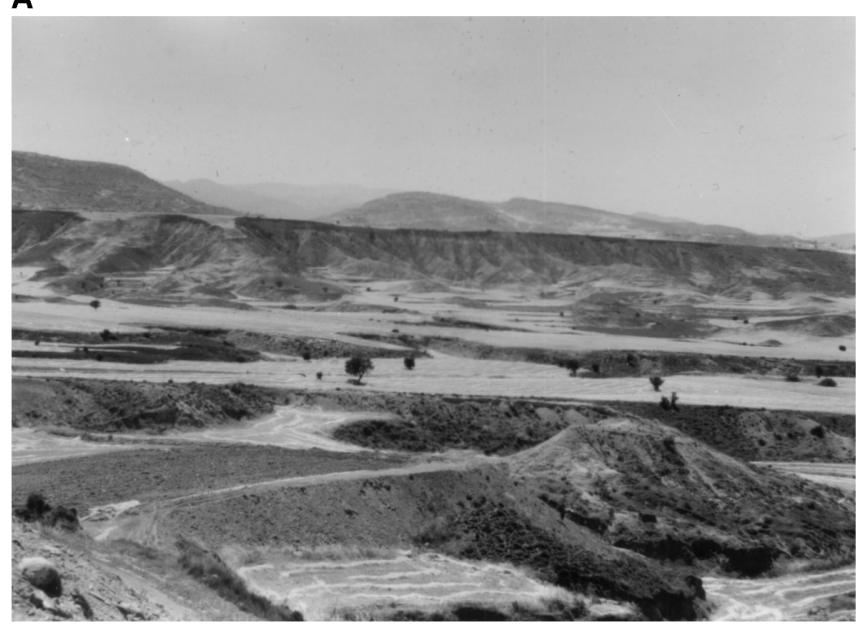

C

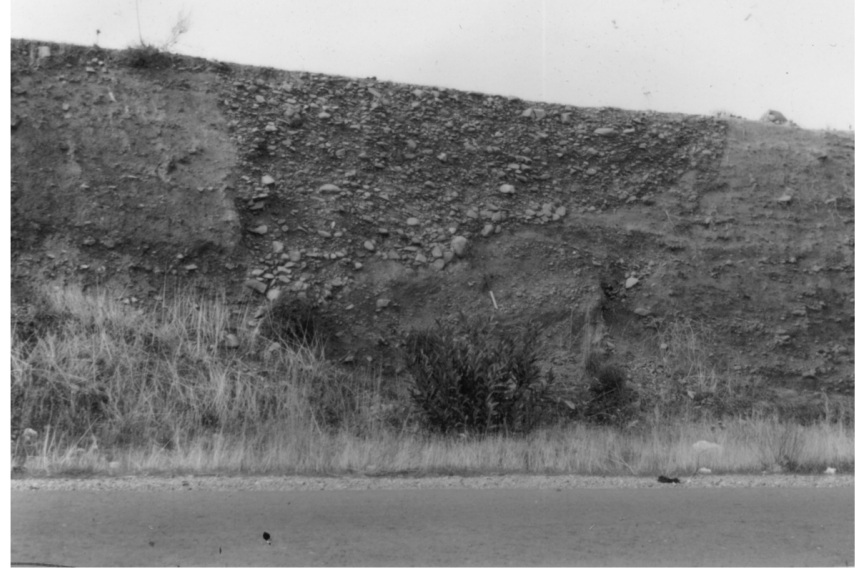

$E$

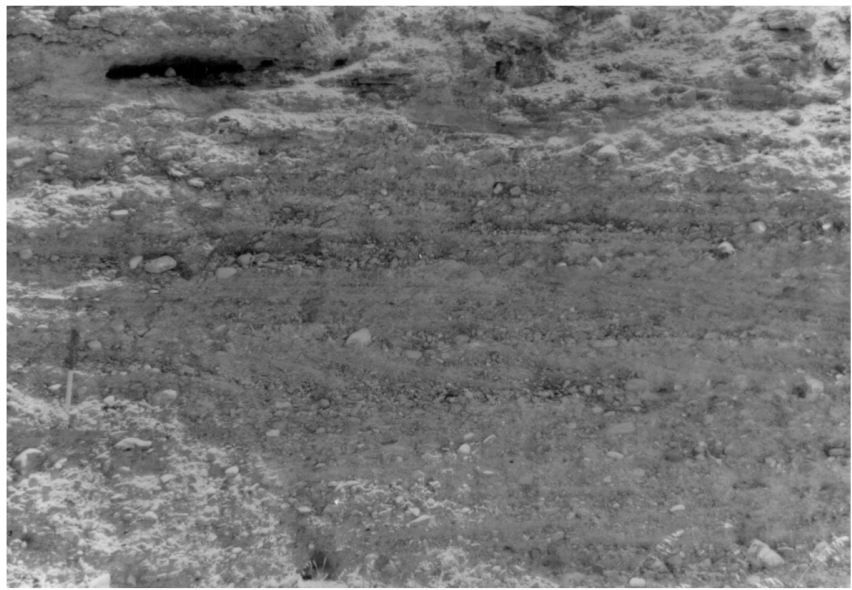

B

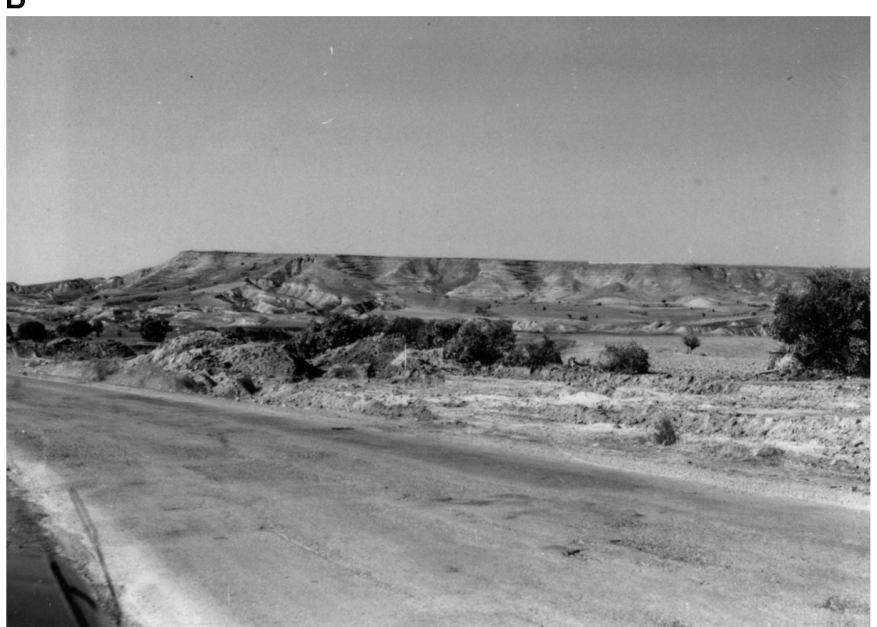

D

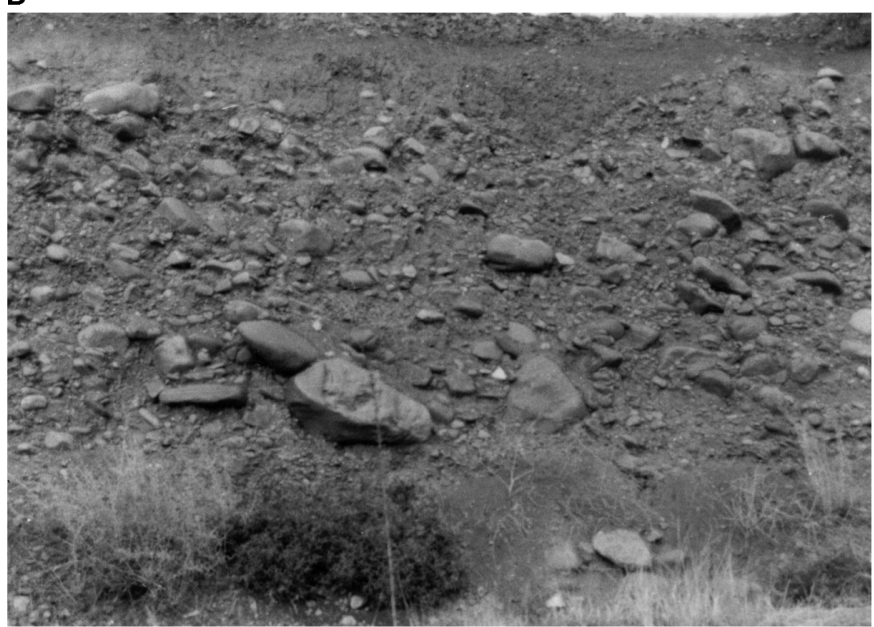

$\mathbf{F}$

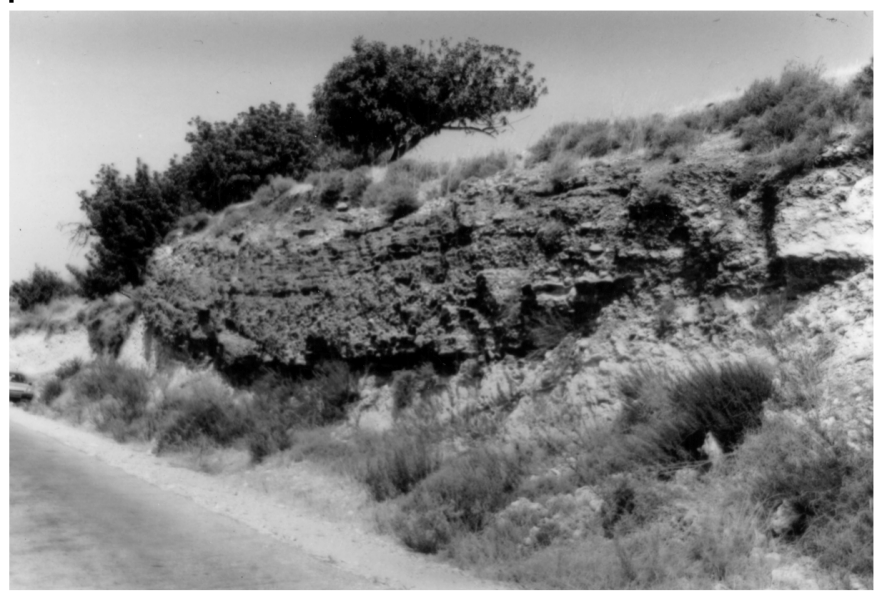

Figure 8. Field photographs. A. View toward Kreatos Hill, north Troodos margin, showing dissection of the F1 and F2 erosional surfaces. B. Erosion surface at Koraka Hill, north Troodos margin, elevated above F2 erosion surface that forms the plain in the foreground. C. F1 age conglomerate cut by F2 age conglomerate channel, Kato Koutraphas, north Troodos margin (loc 1-72). D. Very coarse imbricated basal conglomerate of F2 age, near Vyzakia, north Troodos margin (loc 1-19). E. View east-northeast of small channels and bars in distal F2 channel sequences at Yermasoyia (loc 3-24). F. Large channel of F1 age cutting Miocene chalk at Kouklia, southwestern Cyprus (loc 2-54; loc = location; see Table 2 for details of locations). 
A

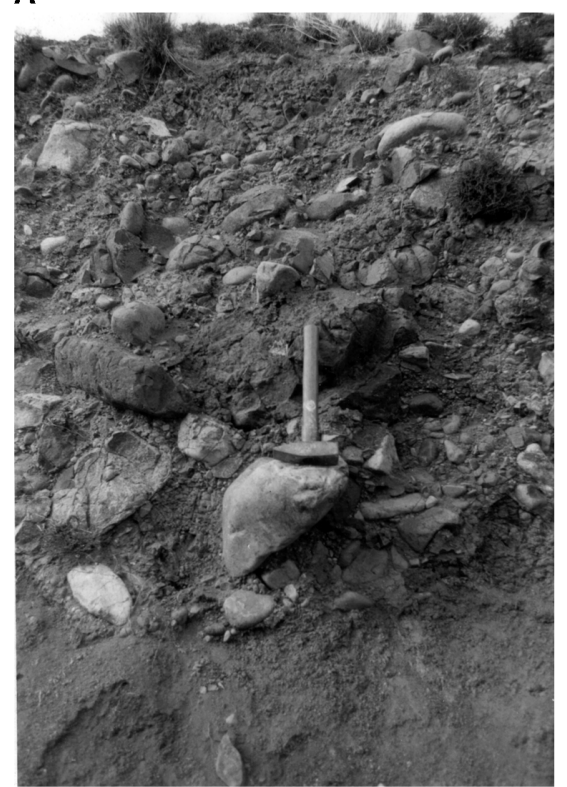

C

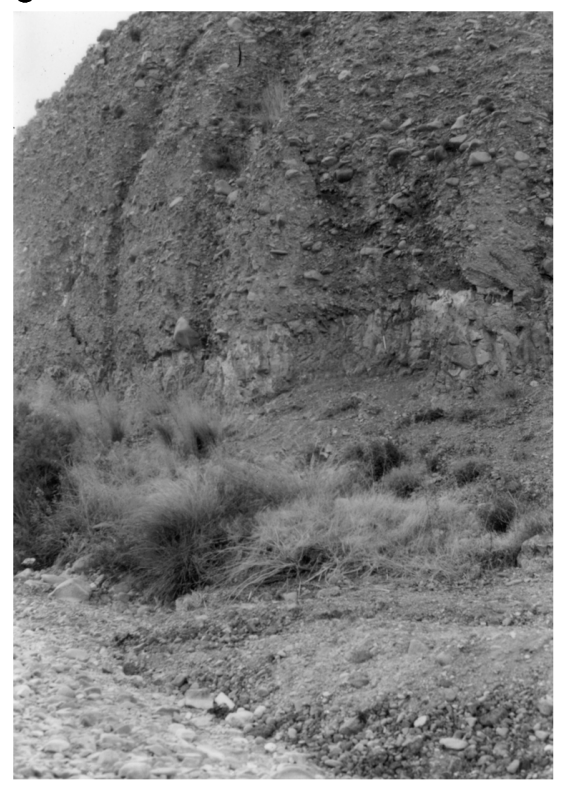

B

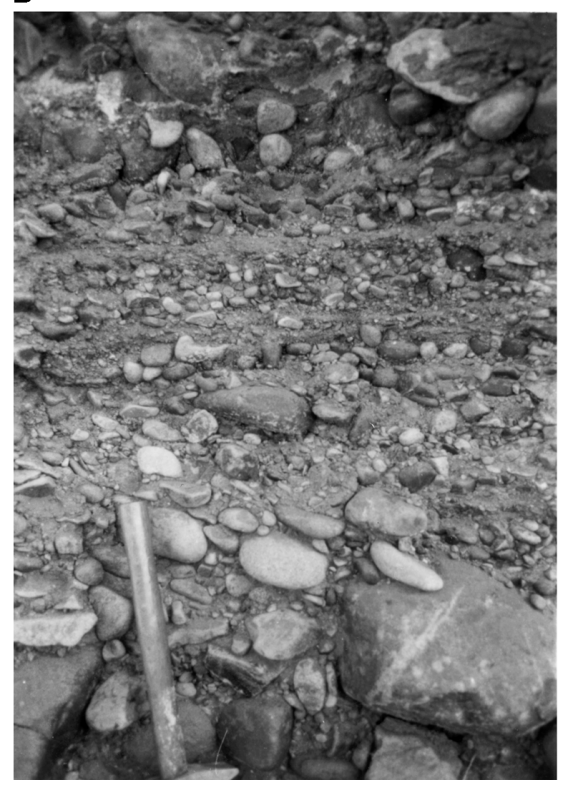

D

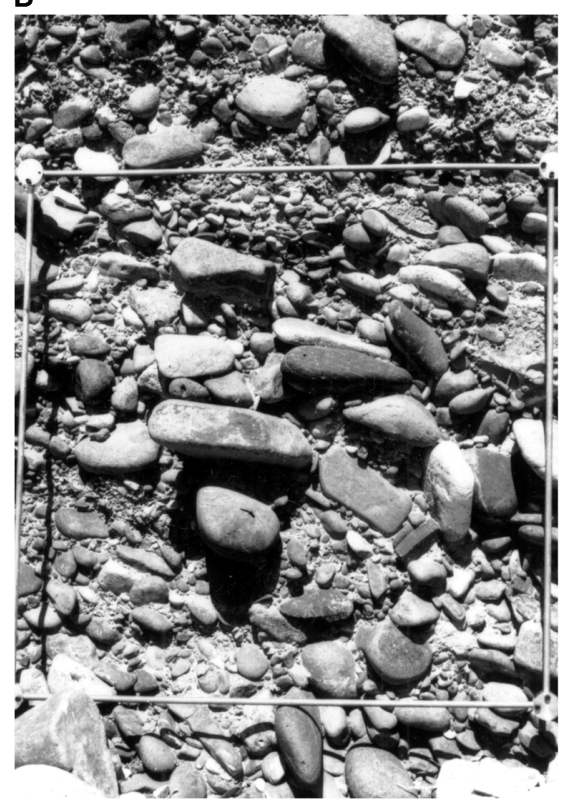

Figure 9. Field photographs of fanglomerate facies. A. Contact between F1 age conglomerate and underlying highly weathered pillow lavas, at Politiko, an intermediate location in the north Troodos margin (loc 1-94). B. F1-age fanglomerate at Peratis Hill showing a coarse, poorly sorted conglomerate fining upward with better sorted medium conglomerate typical of an intermediate location in the north Troodos margin (loc 193). C. F2-age conglomerate unconformably overlying very weathered pillow lavas at Malounda, north Troodos margin (loc 1-7). D. Detail of well-rounded and quite well-sorted F2-age conglomerate at Akhelia, southwest Cyprus (loc 2-45). This also shows a $50 \mathrm{~cm}$ $\times 50 \mathrm{~cm}$ grid used in the clast count analysis. See Table 2 for details of locations. relatively minor uplift took place (McCallum and Robertson, 1990). Thus, rapid uplift in the upper Pliocene soon unroofed ultramafic rocks that were channeled northward by the paleo-Karyotis River, without wider dispersal. However, continuing uplift in the upper Pliocene-mid-Pleistocene unroofed large areas of gabbro and diabase, represented by widely dispersed clasts in the Fanglomerate Group.

The north Troodos margin conglomerates probably formed rapidly by streamflood, or sheetflood, processes, similar to early Tertiary conglomerates in Wyoming (Kraus, 1984) and certain Pleistocene sequences in Spain (Harvey, 1984; Harvey and Wells, 1987). However, the absence of matrix-supported conglomerates in proximal areas of the north Troodos margin probably reflects availability of fine- 

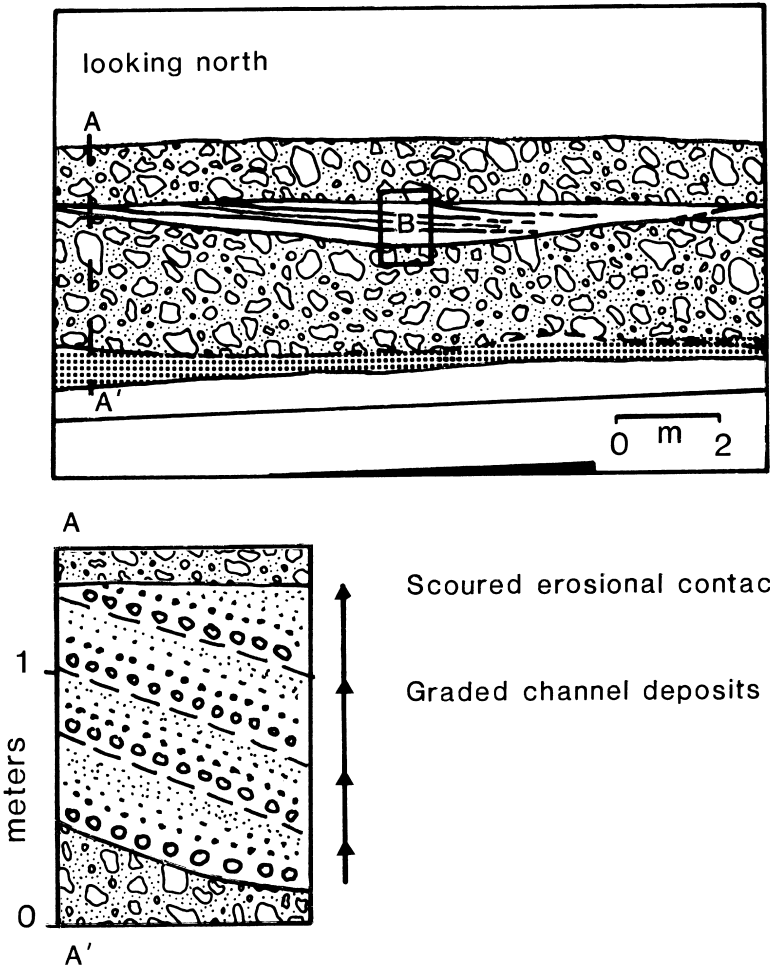

Scoured erosional contact

Graded channel deposits

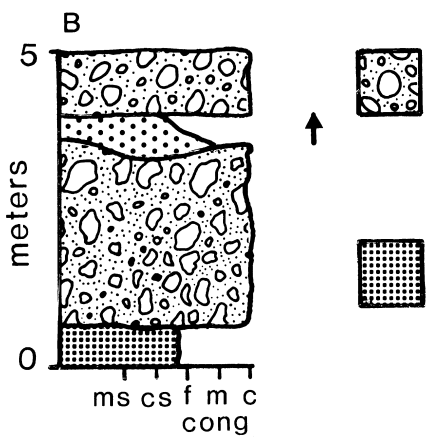

Massive, matrix to grain supported, immature conglomerate. Caliche formation near top of unit.

Massive structureless sands with stringers of igneousderived clasts at the top.

Figure 10. Sketch section of an intermediate location sequence of the Fanglomerate Group along the north Troodos margin near Akaki (loc 1-68; see Fig. 5 and Table 2 for details of locations).

grained sediment and the paucity of soil cover developed in a semiarid climate (e.g., Harvey, 1984). Variable clast fabric within such sheetflood units also reflects the distance of transport and relative viscosity. Short-distance travelled units are generally disorganized. Sheared laminar flow, typical of long-distance travelled units, however, leads to clast interaction and more clast orientation (Lewis et al., 1980). Sheetfloods form extensive thin sheets of massively bedded conglomerate, while streamfloods occur when the channels are too deep for sheetflood development (Blissenbach, 1954). Deposition by sheetflood, rather than streamflood, processes resulted in the deposition of an extensive conglomerate fan sequence on the north Troodos margin.

In the intermediate locations, shallow channels clearly existed, typical of intermediate locations on semi-arid alluvial fans (e.g., Nemec and Steel, 1984, 1988). The presence, or absence, of crossbedding within conglomerate sequences is one indicator of channel depth, with cross-bedding being indicative of deeper channels (Kraus, 1984). Cross-bedding within the intermediate location units is thought to reflect rapid fall in fluid and sediment discharge rates across a bar (e.g., Hein and Walker, 1977), supporting an argument for flashy, ephemeral flow across fans.
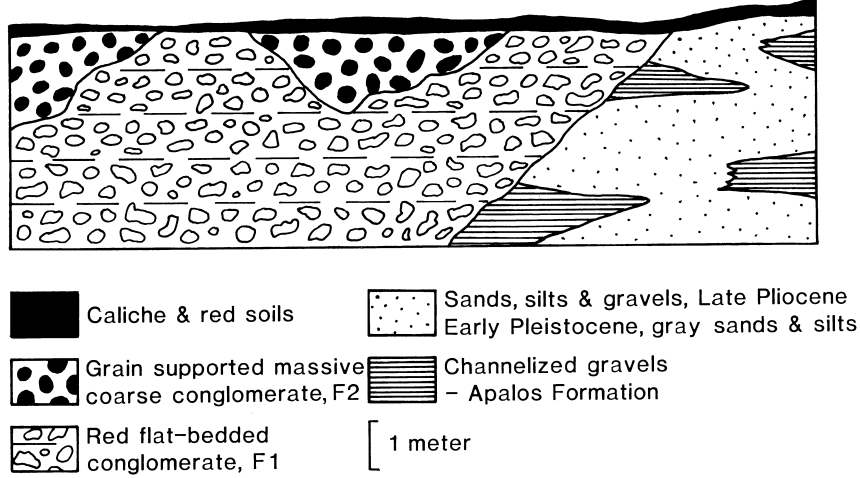

Figure 11. Sketch section of distal sequences (F2) of the Fanglomerate Group on the north Troodos margin near Astomeritis (see Fig. 5).

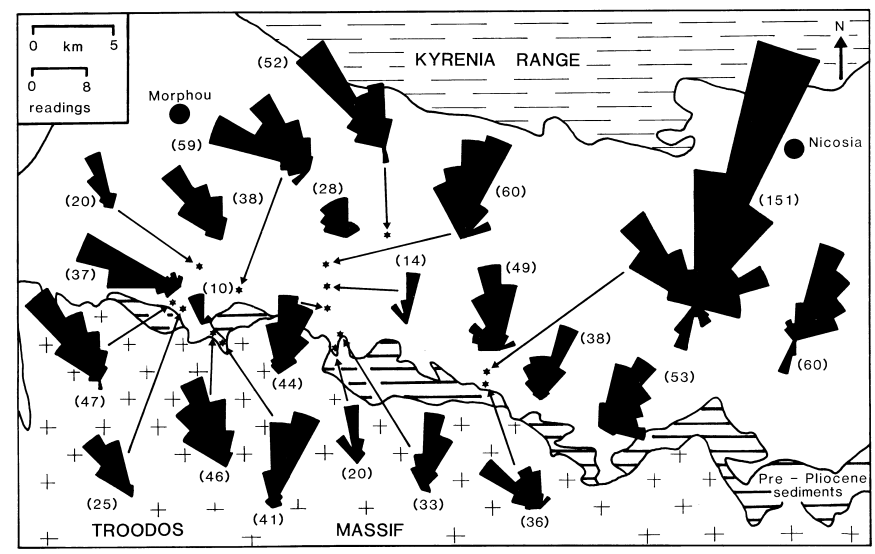

Figure 12. Rose diagrams of paleocurrent data collected from clasts within the Fanglomerate Group on the north margin of the Troodos Massif. Note: the number of clasts measured is indicated.

Distal locations on the north Troodos margin reflect braided stream flow conditions (Miall, 1978), with development of channel cut-and-fill, overbank sediments, and paleosols. These sequences also reflect an overall north-to-south proximal to distal trend across the Mesaoria Plain. Reworking and downcutting probably resulted in substantial reworking of mid- and upper-fan sediments downslope into distal locations.

As uplift continued, the core of the Troodos Massif apparently rose at a faster rate than peripheral areas and the Mesaoria Plain. An important control was the effect of diapiric protrusion of serpentinite from beneath, coupled with isostatic rebound as unroofing took place (England and Molner, 1990). The result was rapid erosion and supply of little-altered Troodos-derived clasts, with increased numbers of diabase and gabbro clasts. Studies of tectonic uplift of source areas in recent alluvial fans (Heward, 1978) indicate that uplift of the hinterland can result in deposition, either on the active fan segment (where the rate of uplift is greater than that of stream dissection), or entrenchment and deposition of a second fan sequence at the toe of the first fan (where the rate of dissection is greater than that of uplift). The second situation results in formation of isolated hills that were dissected during continued fluvial erosion. Both of these situations applied during fan development along the north Troodos margin. The result was, first, deposition of the F1 Fanglomerate unit, and secondly, extensive dissection of the F1 Fanglomerate unit, with fluvial downcutting along the north Troodos margin and development of channel fans and mature erosion surfaces (e.g., Muto, 1987). Distal localities on the Mesaoria Plain were not uplifted as much as proximal areas, allowing a coalescence of the Fanglomerate Group units toward the north. 
Figure 13. Clast-analysis data from the Fanglomerate Group on the north margin of the Troodos Massif (Mesaoria Plain). Note: the "F" number refers to the Fanglomerate unit from which the clasts were sampled and the number of clasts counted is given in parentheses. Clast categories: (a) ultramafics; (b) mafics (i.e., gabbro); (c) diabase; (d) basic extrusive (i.e., basalt); (e) sedimentary rocks (e.g., limestone). For the clast analysis, 50 randomly selected clasts were identified within each quadrant, according to published methods (Boggs, 1969; Tucker, 1988).

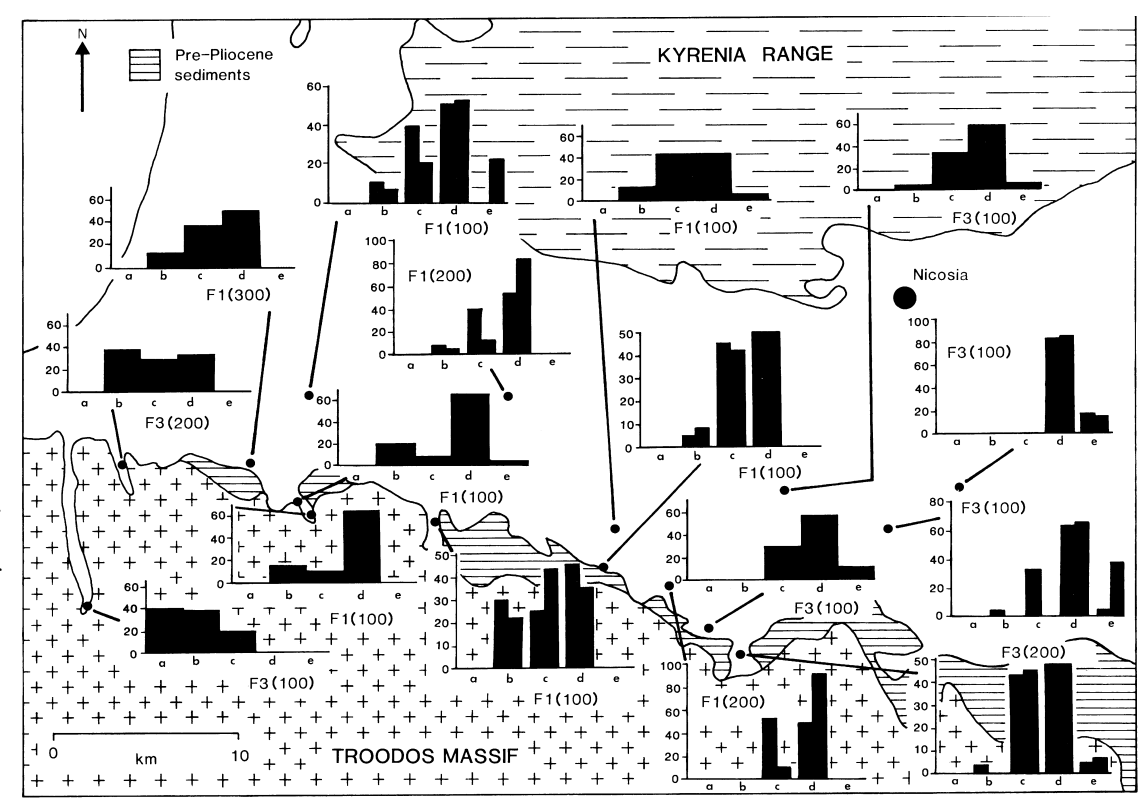

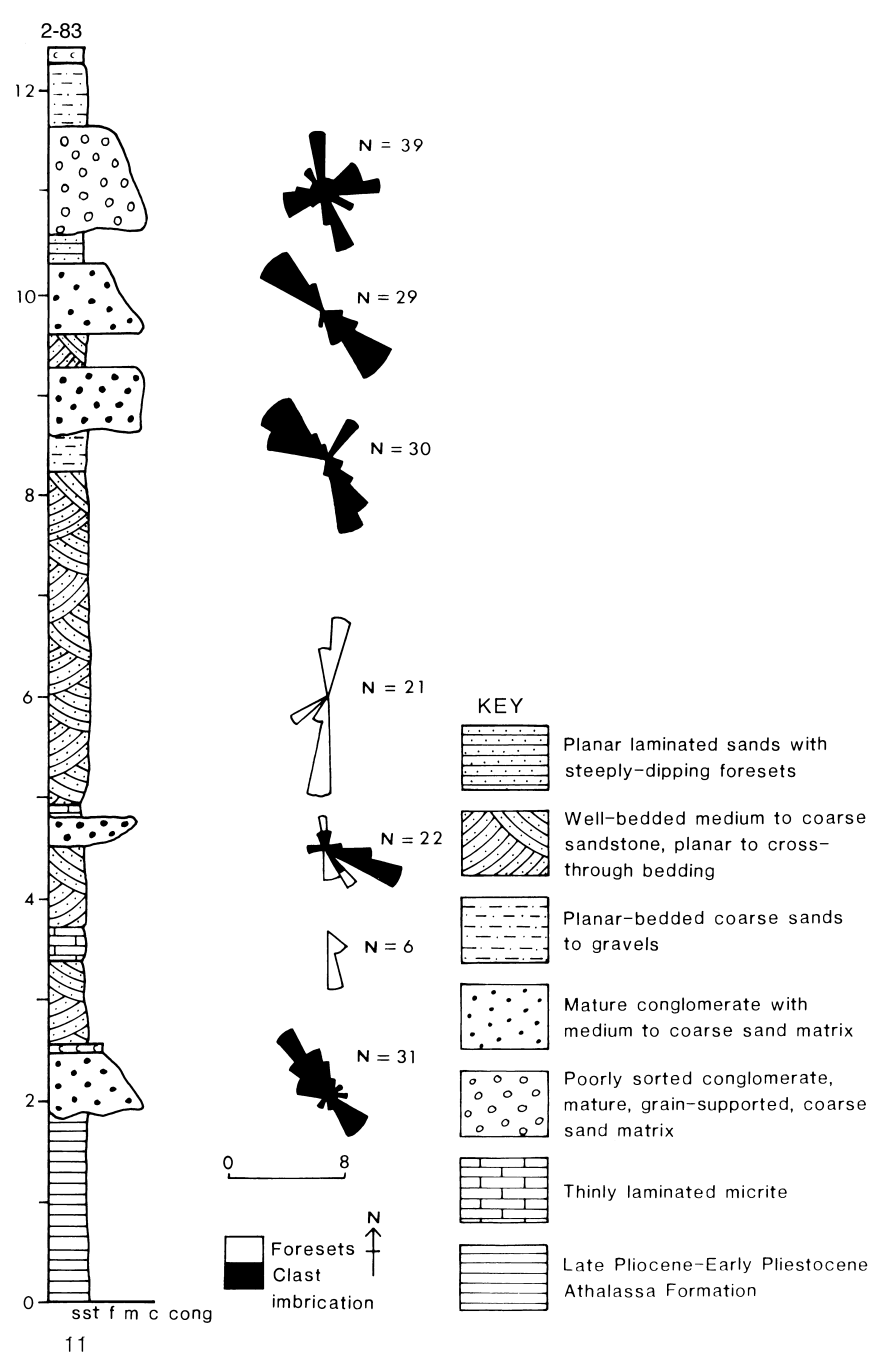

Figure 14. Log of the Fanglomerate Group from southeast Cyprus (F2; Dhekelia area). Location is indicated in Figure 2 as location 11; see also loc 2-83 in Table 2.

\section{Southeastern Area}

We now go on to summarize information concerning other Pleistocene clastic sediments in the southern part of Cyprus. The Fanglomerate Group in southeastern Cyprus, around Dhekelia, represents a southeasterly extension of the Mesaoria Plain deposits that in some areas unconformably overlie Pliocene shallow-marine carbonates (i.e., Athalassa Formation; Poole and Robertson, 1991). The succession resembles that at distal locations on the north Troodos margin, with channelized, poorly sorted, massive, immature, coarse conglomerates, interbedded with mature sands and conglomerates (Fig. 14, $\log 11)$. As in distal areas of the Mesaoria plain F1 and F2 conglomerates have merged and are not easily distinguished. Paleocurrents are mainly toward the southeast (Fig. 15). Clasts present within the unit include basalt, diabase, gabbro, chalk, and chert. Imbrication data indicate variable paleocurrents (Poole, 1992). The fanglomerate unit is capped by caliche and red terra rossa-type soils that form a thin cap over much of the area. The presence of interbedded Pleistocene shallow-marine sediments near the present coast indicates proximity to a shoreline during deposition.

One feature of note is the presence of a local bone bed southwest of Xylophagou that consists of well-cemented, mature, green sandstone, overlain by coarse, poorly sorted, unfossiliferous, red conglomerates. The presence of igneous and sedimentary clasts of grainstones, limestones, diabase, gabbro, and basalt indicates derivation mainly from the Troodos ophiolite and its local sedimentary cover. These conglomerates are overlain by calcarenites, silts, sands and poorly sorted, grain-supported conglomerates. The bone bed unit may be correlatable with the F3 Fanglomerate Unit of the northern Troodos margin. The matrix encasing the mammal bones is wellsorted, submature, fine- to medium-grained sand. Thin-section analysis reveals ophiolite-derived grains and minerals (lava, diabase, feldspar, and pyroxene), sedimentary clasts and <2-mm-long reworked fossils, such as benthic and planktonic foraminifers and abraded mollusc fragments, cemented by sparry calcite. Delicate ostracode shells are locally concentrated within the matrix and are probably in situ, consistent with a lacustrine setting.

In southeastern Cyprus the sedimentary clasts are dominated by Paleogene and Neogene chalks and limestones. An unusually high proportion of lava clasts locally at Dhekelia reflects additional input from a nearby ophiolite inlier, the Troulli Inlier. By contrast, gabbro clasts were either derived from isolated gabbroic outcrops in the eastern Troodos ophiolite, or from the main gabbro outcrop in the core of 


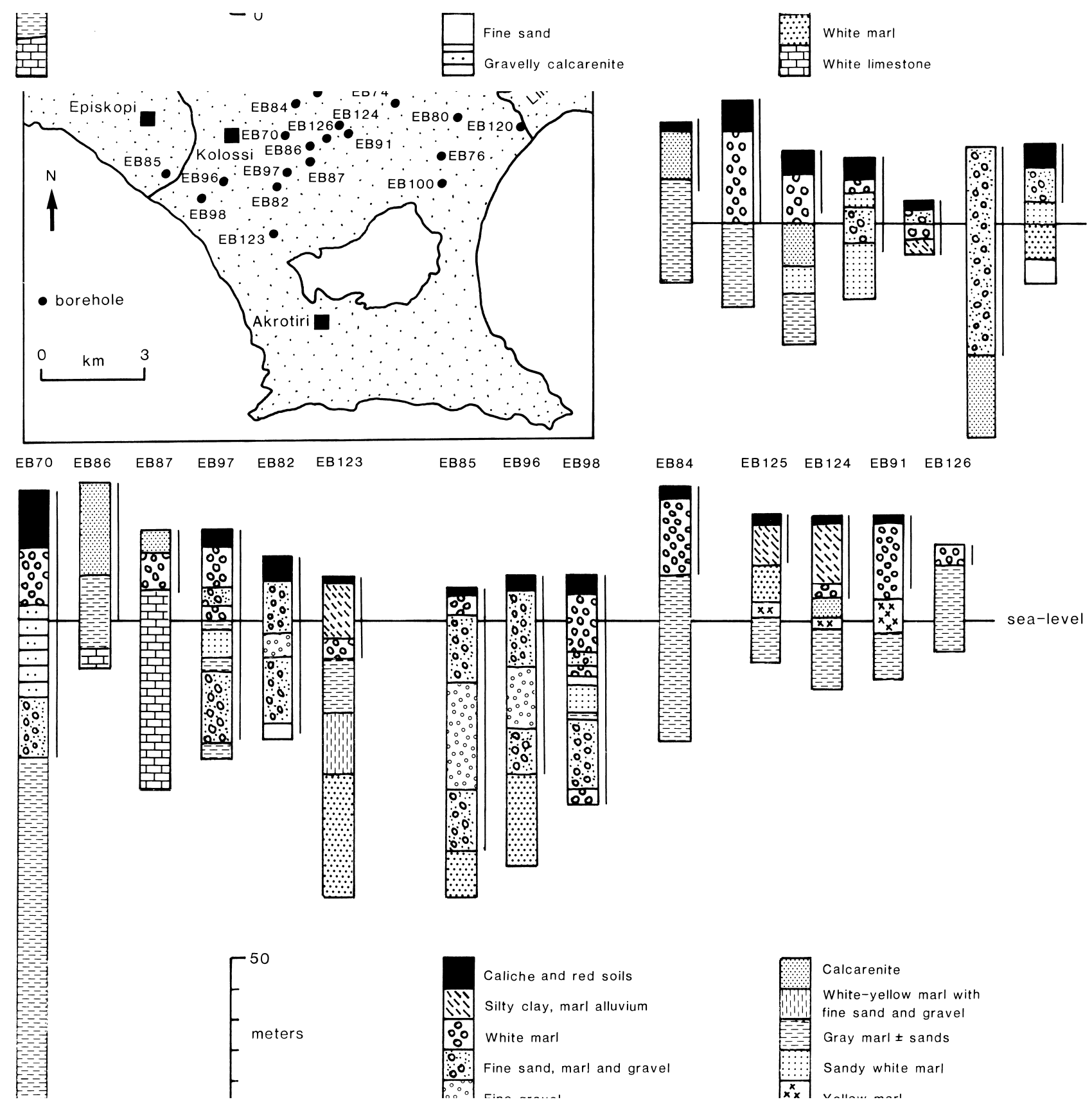

Figure 15. Borehole data from the Akrotiri Peninsula, south Cyprus, showing possible thicknesses of the Pleistocene succession. The possible extent of the Pleistocene units is marked with vertical lines.

the Troodos Massif. Derivation from the eastern Troodos Massif is likely, as present-day rivers in this area, such as the Yialias, flow generally north then east, in contrast to rivers draining the intrusive core area that eventually flow westward into Morphou Bay. The gabbro clasts thus imply the former existence of a drainage system flowing generally southeastward through the Dhekelia area into Larnaca Bay.

\section{Southern Coastal Area}

Development of the Fanglomerate Group inland along the southern coast, between Larnaca and the west side of the Akrotiri Peninsula. However, greater thicknesses are recorded in boreholes from the
Akrotiri Peninsula (Fig. 15). Correlation of the Fanglomerate Group westward from southeastern Cyprus is possible using relative altimetry and correlation with depositional terraces and erosion surfaces. Correlation at coastal sites was achieved by an association with marine terraces (Poole and Robertson, 1991). Four Fanglomerate units are identified in this area, based on topographic height and lateral correlations.

\section{F1 and F2 Fanglomerate Units: Lower-Middle Pleistocene}

The combined F1 and F2 Fanglomerate units in coastal southern Cyprus are restricted to small, thin, patchy outcrops. These are ac- 
companied by the development of terraces within $80 \mathrm{~m}$ of basement units in the lower Vasilikos Valley (Gomez, 1987). F1 commonly consists of clasts derived from the Troodos ophiolite and its sedimentary cover (e.g., northwest of Tersephanou). The F1 unit locally overlies chalks of the Lefkara Formation. Gomez (1987) also distinguished between our F1 and F2 Fanglomerate units in the lower Vasilikos Valley (i.e., this Phalakros and Mitsinjites terraces).

The F1 and F2 Fanglomerate units of the southern margin of the Troodos Massif form isolated remnants capping hills (e.g., near Limassol). Successions are commonly 3-4 m thick and resemble those exposed on the north Troodos margin. Coarse immature, poorly sorted, matrix- to grain-supported conglomerates dominate, with subordinate amounts of finer-grained clastic sediments, red terra rossatype paleosols and caliche horizons. Two distinct units of coarse conglomerate separated by finer sediments, caliche and paleosols, were observed at a number of localities, for instance, northeast of Zyyi and south of Mari (Figs. 2, 16). Subangular clasts of lava, diabase, and chalk predominate, together with locally abundant chert, limestone, gabbro, and ultramafics. Troodos igneous-derived clasts are commonly more mature than those derived from the sedimentary cover.

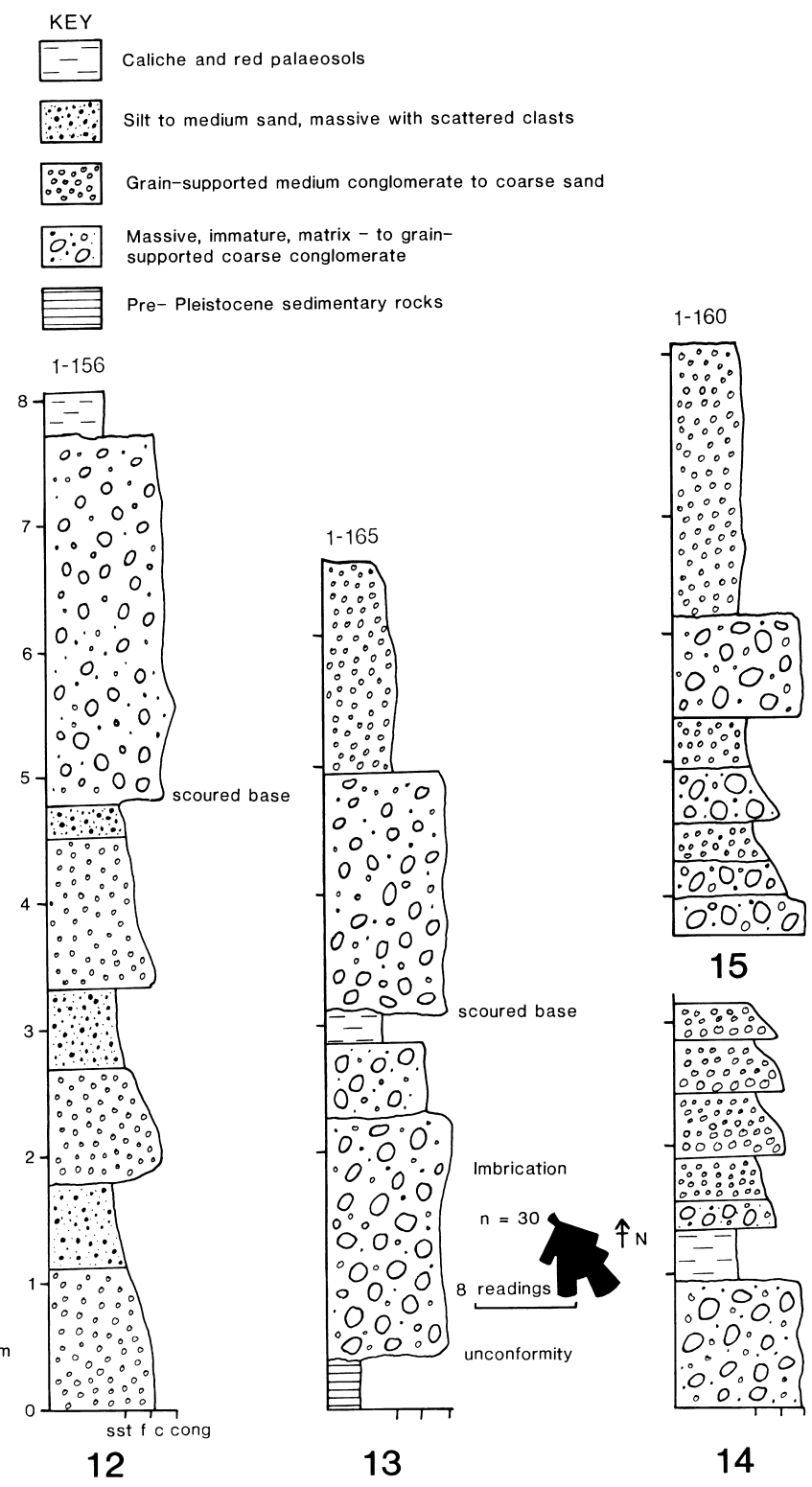

Figure 16. Logs of the F3 Fanglomerate unit (i.e., early late Pleistocene) from the south coast of Cyprus. See text for explanation. Locations are shown as numbers $12-15$ on Figure 2 and in Table 2.
The proximal F1 Fanglomerate, equivalent to the Vasilikos Formation of McCallum (1989), can be correlated with conglomerates in southwestern Cyprus (see below). The more distal F1 and F2 Fanglomerate units in southern Cyprus resemble the fanglomerates of southeastern Cyprus and distal outcrops of the north Troodos margin. These include coarse conglomerates, well-bedded, fine and medium conglomerates, sands, paleosols, and caliche horizons. The coarse conglomerates are poorly sorted, immature and massive, although some crude bedding is locally present (e.g., in the Limassol area; Fig. $8 \mathrm{E})$. Clasts are generally $30-40 \mathrm{~cm}$ long, subangular and relatively immature. "Outsize" clasts up to $70 \mathrm{~cm}$ long are locally present. In addition to coarse conglomerates, there are also mixed sediments north of Limassol, locally composed of relatively mature, bedded conglomerate with a relatively high proportion of sand and silt.

\section{F3 Fanglomerate Unit: Early-Late Pleistocene}

The F3 Fanglomerate unit along the southern coast of Cyprus crops out in many of the large river valleys (e.g., Kouris and Pendaskinos Rivers; Fig. 3). The F3 sections generally occur up to $15 \mathrm{~m}$ above the present-day channels incised into the F1 and F2 deposits. Massive, structureless, grain- to matrix-supported coarse conglomerates are overlain by more mature, generally well-bedded and wellsorted conglomerates, sands, and silts (Fig. 16, logs 12-14). The well-bedded units are locally graded and are commonly interbedded with paleosols and caliche horizons. The tops of the well-bedded units are often scoured and overlain by an additional unit composed of coarse, structureless conglomerate. Exceptions to the typical sequence include the following: (1) conglomerates within well-bedded units (e.g., at Khirokitia and north of Maroni); (2) extensive areas of fine sand and silt capped by coarse, immature, conglomerate, 50-60 $\mathrm{cm}$ thick; (3) well-developed paleosols and caliche horizons between basal, massive conglomerate and overlying well-bedded units (e.g., south of Maroni).

\section{F4 Fanglomerate Unit and Younger Fluvial Sediments: Late Late Pleistocene-Holocene}

The F4 Fanglomerate unit is best exposed in major river valleys issuing from the Troodos Massif and in coastal areas (Fig. 17, logs 15-17). Exposures in the valleys are incised into the F3 Fanglomerate unit. For example, excavation pits in the lower Vasilikos Valley (Gomez, 1987) show 3- to 5-cm-thick rhythmic cycles. Sands and silts cover much of the valley floor, but massive, poorly sorted, immature conglomerates are also present. The conglomerates are generally grain-supported and incorporate clasts up to $60 \mathrm{~cm}$ in size. Clasts of lava and diabase predominate, together with immature chalk clasts. Local caliche forms crusts on many clasts.

The F4 unit has locally cut down into the underlying Troodos sedimentary cover in the Maroni River valley, showing that the F4 unit was not purely aggradational. Valleys of the southern Troodos margin, such as the Pendaskinos River valley, are presently about 300$400 \mathrm{~m}$ wide and commonly covered in alluvium; many today contain misfit streams.

The F4 Fanglomerate units are locally well exposed along the coast at Zyyi and Petounda Point, where sections are undergoing marine erosion. Successions are generally less than $2 \mathrm{~m}$ thick and dominated by massive, poorly consolidated, coarse conglomerates, wellbedded sandstones, fine gravels, and paleosol horizons (Fig. 17, logs. 15-17). The dominant clasts within the conglomerate units are chalk, basalt, and diabase.

Offshore shallow seismic profiles reveal channels of inferred F4 age that can be correlated with fluvial channels onshore (e.g., at Zyyi; McCallum et al., 1993). Onshore, shallow conglomerate-filled channels are incised into floodplain conglomerates, similar to those associated with the F4 Fanglomerate unit along the southern margin of the Troodos Massif.

There is also local evidence of Holocene to present-day fluvial processes. The floor of the Vasilikos Valley shows evidence of addi- 


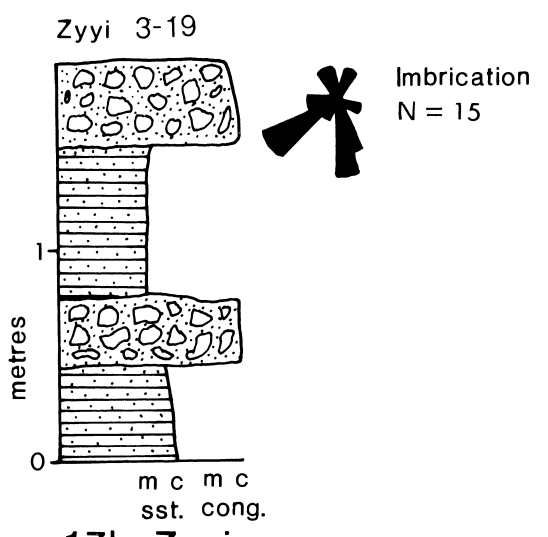

17b. Zyyi

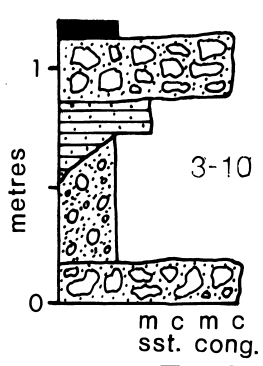

17a. Zyyi

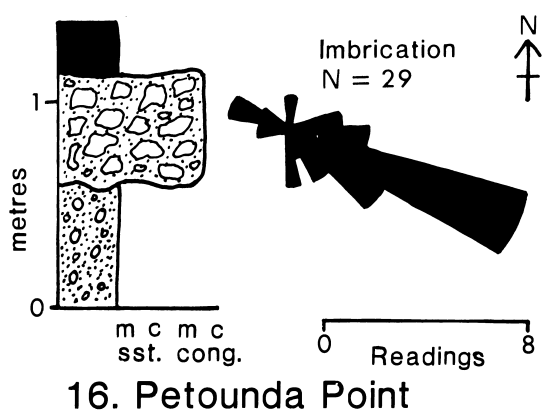

KEY

Red soils
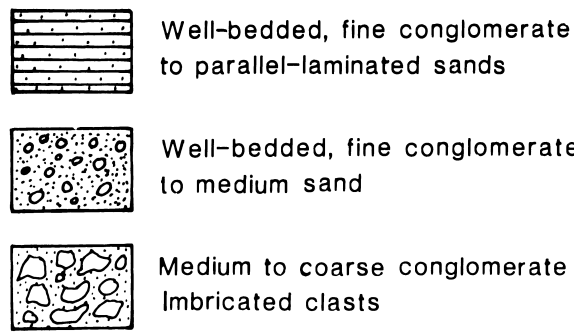

Figure 17. Logs of the F4 Fanglomerate unit (i.e., late late PleistoceneHolocene) cropping out in southern Cyprus. See text for explanation. Locations are shown in Figure 2 as locations 16, 17 and in Table 2.

tional downcutting by $6 \mathrm{~m}$. This was followed by a period of aggradation and alluviation between 5540 to 5010 B.C. (Gomez, 1987). The aggradation was succeeded by fine-grained overbank sedimentation and subsequent downcutting to form an alluvial terrace within 2 $\mathrm{m}$ of the present floodplain, as seen in the Tremithios Valley. Incision into this terrace has occurred since Byzantine (i.e., 330-1190 A.D.) times (Gifford, 1978). The conglomerate units cap silty and sandy alluvium in many places. Muddy, poorly sorted alluvium was also deposited in the Tremithios River in the Larnaca lowlands during the latest Pleistocene and early Holocene.

\section{Paleocurrent and Clast Data}

Paleocurrents are directed southward in south-coastal Cyprus, reflecting a regional radial drainage pattern centered on Mt. Olympos (Fig. 18). Within individual areas there was little change in flow direction during the Pleistocene. Minor changes include a trend from dominantly east-southeast to south-southeast during deposition of the F2 and F3 Fanglomerate units. Such local deviations are observed in fluvial sequences deposited away from restricted valley fan systems, within more distal areas of lower river gradients. The drop in gradient and removal of any lateral constraints on fluvial flow in these areas allowed braidplains with variable paleocurrents to develop in low coastal plains.

Clasts within the F3 and F4 Fanglomerate units are similar throughout the southern area (Fig. 19). In general, ophiolitic clasts are more mature than more locally derived sedimentary rock in the F3 Fanglomerate. The proportion of chalk clasts is generally higher in the F3 Fanglomerate unit than in the F4 Fanglomerate unit. Local gabbro clasts were probably derived from small outcrops of plutonic rocks in the upper reaches of the Maroni River.

The clast data from the southern area show a progressive increase in the proportion of ultramafic clasts through time (e.g., in the Kouris River), matched by a decrease in the relative proportion of diabase and lava clasts. Ultramafic clasts are absent from the F1 Fanglomerate unit, but are then present in the F2, F3, and F4 Fanglomerate units as far east as Vasilikos. The proportion of mafic clasts varies locally in units to the north and east of Limassol (as far as Vasilikos), while the proportion of sedimentary clasts remained relatively constant (Fig. 19).

The Limassol Forest differs from the Troodos, further north, in that it was deformed by south-vergent thrusting during the early Miocene, so that intrusive ophiolite rocks such as gabbro and ultramafics were exposed at high structural levels (Eaton, 1987; Eaton and Robertson, 1993), and later transgressed by late Miocene shallowwater carbonates (Follows, 1990; Follows et al., 1996). These cover sediments were finally removed in the early to middle Pleistocene. There was thus a source of plutonic clasts within the Limassol Forest area that does not document uplift of the Troodos core, other than the Kouris River that drains Mt. Olympos.

\section{Discussion}

F1 and F2 Fanglomerate deposition in coastal southern Cyprus was controlled by a series of large channels, some of which date back to the upper Pliocene and possibly to the Miocene (Eaton, 1987). Local channel incision (e.g., at Khirokitra) marks the onset of rapid uplift in this area during the Late Pliocene (Houghton et al., 1990). Huge volumes of sediment were supplied by the paleo-Kouris River which probably fed a large channel fan, explaining the abundance of fanglomerate present in boreholes in the Akrotiri Peninsula. Channel fans also formed elsewhere along the southern coast, with much sediment by-passing and deposition in the sea south of Cyprus. Turbidites, interbedded with deep-sea muds were cored at Site 968 at the foot of the slope of the Cyprus margin. These contain abundant terrigenous material derived from the Troodos ophiolite and its sedimentary cover (Emeis, Robertson, Richter, et al., 1996; Robertson, Chap. 36, this volume).

An overall proximal to distal change in clastic sedimentation is seen along the southern margin of the Troodos Massif during F1-F4 times. This probably reflects repeated progradation of a fluvial system from proximal channelized fans (e.g., Muto, 1987; Heward, 1978) to form an unconstrained alluvial plain. Channels widened with the development of bars and channels in distal areas, while sheetflood-streamflood processes were prevalent in confined chan- 


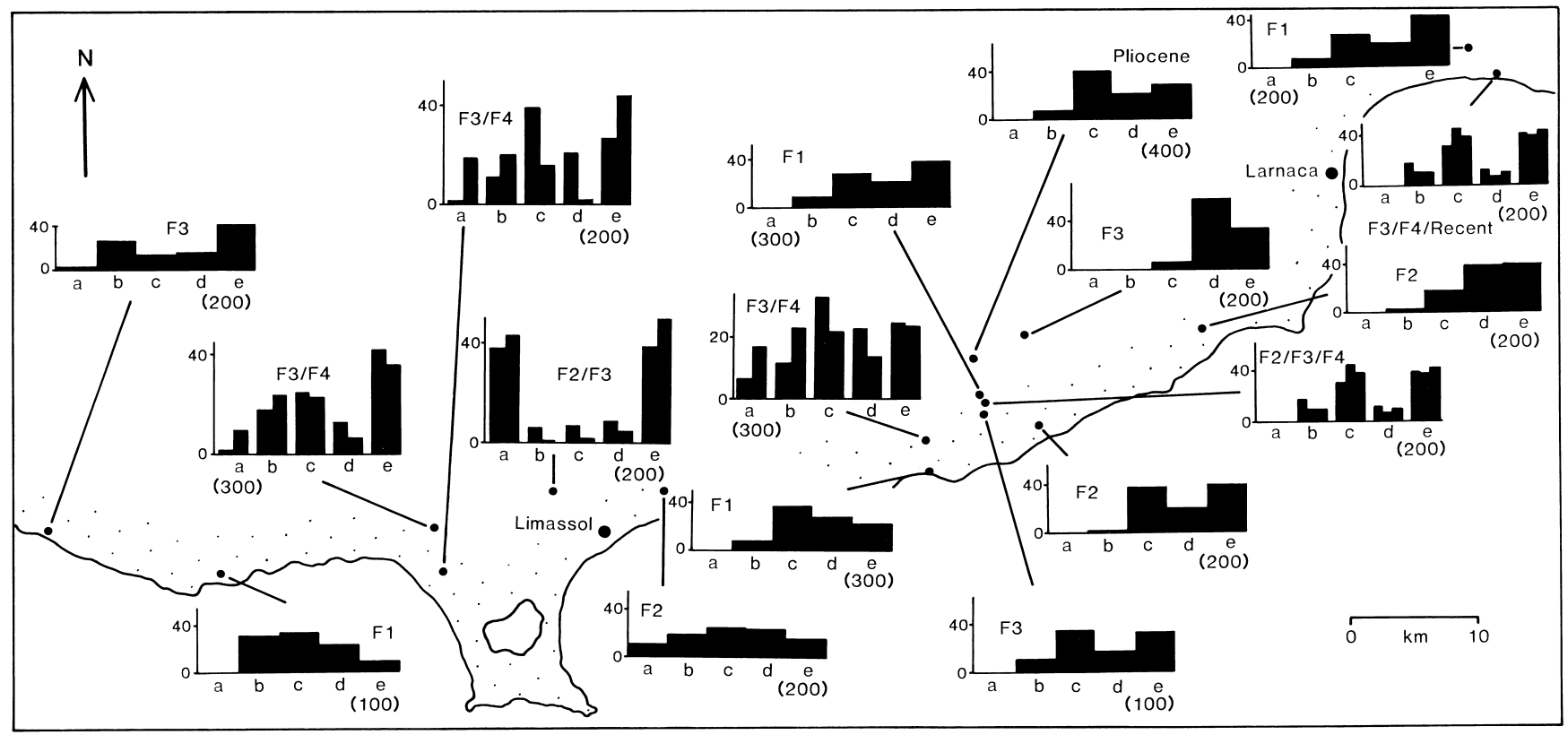

Figure 18. Clast analysis data from the southern coastal area. "F" number refers to the fanglomerate unit; number in parentheses is number of clasts counted; clast categories: (a) ultramafics; (b) mafics (i.e., gabbro); (c) diabase; (d) basic extrusives (i.e., basalt); (e) sedimentary rocks (e.g., limestone).

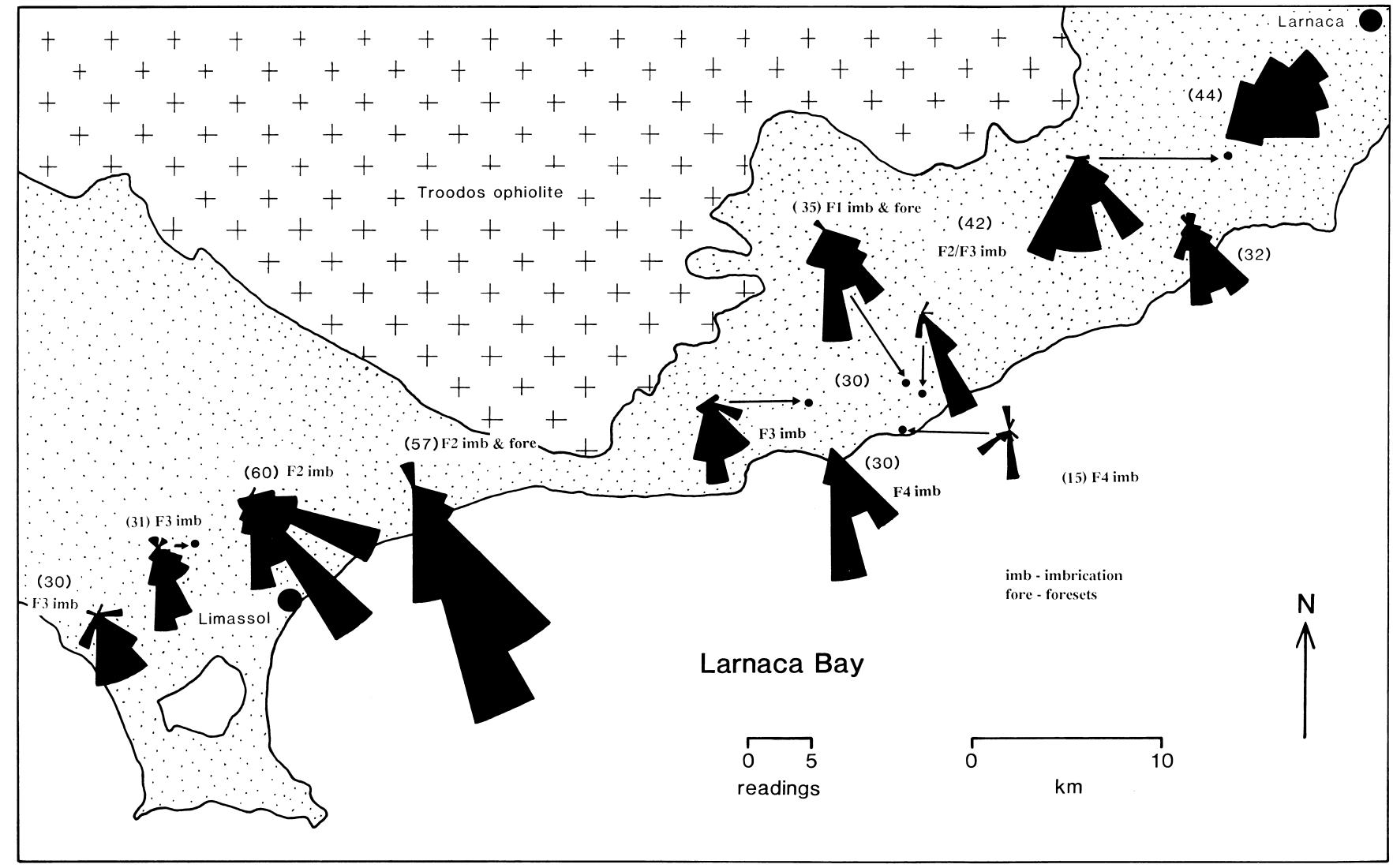

Figure 19. Paleocurrent data from the Fanglomerate Group along the southern coastal area of Cyprus. Number of measurements is given in parentheses. The " $F$ " number refers to the fanglomerate unit (e.g., F1). 
nels closer to the margins of the Troodos Massif. The development of braidplain sequences accounts for increased sorting of sediments away from confining channels, with the presence of grain- rather than matrix-supported conglomerates. Periodic flood events carried an immature, poorly sorted sediment load onto the alluvial plain, where it was deposited beyond the confines of restricted channels. In addition, gravelly sediments, interpreted as sheetflood and streamflood deposits, comprise a minor proportion of the exposed Fanglomerate Group in coastal southern Cyprus, where channelized braid sequences dominate.

The F4-Holocene Fanglomerate units reflect deposition of coarse conglomerate, with an increasing proportion of fine alluvium. The coarse conglomerates are attributed to high-energy, bedload deposition, passing up into stratified bar deposits. The fine-grained alluvium is interpreted as overbank deposits. Gomez (1987) relates the sediments in the lower Vasilikos Valley with the "Older Fill" and "Younger Fill" of Vita-Finzi (1969). The presence of two distinct phases of sedimentation in the Vasilikos Valley, unstratified conglomerates and channel sediments, and of two coarse pulses of conglomerate in coastal exposures at Zyyi and at Petounda Point, suggests the existence of two regionally extensive units. Recent coarse conglomerate pulses within the Vasilikos Valley are attributed to deforestation during Roman times (Gomez, 1987). The size of clasts within these Holocene conglomerates suggests that flows had become significantly less intense than during the Pleistocene (F1-F4 Fanglomerate units).

\section{Southwestern Area}

Successions are as follows, working clockwise round the coastal areas from Pissouri to Paphos (Figs. 3, 20, logs 18-21).

In the southern part of this area the Fanglomerate Group is mainly represented by the F1 Fanglomerate unit that is locally exposed in cliffs, about $100 \mathrm{~m}$ above sea level (i.e., in the Pissouri area). The Fanglomerate unit there unconformably overlies Pliocene conglomeratic fan-delta and marl sequences. The succession consists of about $5 \mathrm{~m}$ of laterally variable, poorly cemented, broadly fining-up, channelized conglomerates, overlain by red terra rossa-type paleosols and thick caliche, and then by a mature erosion surface. Clasts of gabbro, diabase, and basalt in the conglomerate units were derived from the Troodos ophiolite, together with chalk and marl that were more locally derived from the sedimentary cover (i.e, Lefkara and Pakhna Formations).

To the northwest, near Paphos, small remnants of pre-Fanglomerate Group conglomerates and paleosols of probable late Pliocene age, were followed by deposition of channelized conglomerates (from 80 $\mathrm{m}$ lower). Fanglomerate Group channels, $40-50 \mathrm{~m}$ wide and up to 3.5 $\mathrm{m}$ deep, are cut down into underlying marls of the Miocene Pakhna Formation (Fig. 8F). In one such channel a basal unit of coarse conglomerate fines up into fine gravels, followed by a second coarse conglomerate that was eroded into finer-grained sediments. Another channel further west is similar but lacks a distinctive basal lag. Clast compositions in both channels are similar, although the second channel contains a higher proportion of locally derived sedimentary clasts. The channelized sequence is correlated with the F1 deposition elsewhere, and is overlain by a well-developed erosion surface. The F2 erosion surface to the south clearly lies topographically beneath (e.g., near Kouklia).

Channeled, fluvial sediments of both the F1 and F2 units, exposed between Yeroskipos and Kouklia, and near Akhelia (Fig. 9D), comprise alternations of conglomerate, fine silt, and sand. These units are generally poorly sorted and immature, with caliche and soil formation. Channels range from $1.3 \mathrm{~m}$ wide and $20-30 \mathrm{~cm}$ deep, to $1 \mathrm{~m}$ wide and 50-60 cm deep.

F3 and F4 Fanglomerate units are also well exposed in coastal and river sections (e.g., east of Paphos). These units topographically lie beneath the F1 and F2 deposits and form part of a contemporaneous coastal plain. Coastal successions are generally $<2 \mathrm{~m}$ thick and comprise alternating coarse, grain-supported, massive conglomerates and fine sands and silts. River sections consist of well-bedded, alternating conglomerates, sands and silts, in cyclic, laterally impersistent beds. Fluvial sequences further inland (e.g., near Kissonerga) include extensive fine-grained sediments composed of white to buff, locally red, medium-grained sands and silts interbedded with minor conglomerates. Clasts are locally imbricated, poorly sorted, immature, angular to rounded, and are mainly chalk, chert, and marl, with some gabbro and serpentinite. The conglomerates range from clast-supported units in channels, to matrix-supported units, interbedded with the fine sands and silts. The clasts are generally $<10 \mathrm{~cm}$ long, but locally up to $25 \mathrm{~cm}$ long. Fining-up sequences are individually structureless, although bedding-parallel lamination are locally present. Beds are laterally persistent over 30-100 m. Impersistent cross-cutting channels are up to $3 \mathrm{~m}$ wide and 50-60 $\mathrm{cm}$ deep.

\section{Provenance of Clasts and Paleocurrents}

A wide variety of sedimentary clasts-chalk, chert, quartzite, marl, limestones, sandstone, siltstone, and mudstone - is found within the F1-F4 Fanglomerate units of the southwestern area. These clasts were derived from the Troodos ophiolitic rocks, from their overlying sedimentary cover, and from the Mesozoic Mamonia Complex (Fig. 21). Clasts locally derived from the Mamonia Complex are widely present north and east of Paphos (e.g., in the Kissonerga area). Ultramafic clasts commonly reflect a Mamonia, rather than Troodosderived, source. However, where major rivers such as the Ezousa, Yerapotomos, and Dhiarizos drain the Troodos Massif, far-travelled diabase clasts are common. The proportion of clast types in southwestern Cyprus remained generally constant throughout the Pleistocene, reflecting the persistence of diverse sources, represented by the Mamonia Complex, the Troodos ophiolite, and the sedimentary cover sequence of both these units.

Paleocurrent data (Fig. 22) indicate a continuation of a broadly radial pattern of sediment dispersal observed in other areas, but with some local variation. Notably, southerly paleocurrents in the north reflect derivation from the Akamas Peninsula, a topographic high in northwestern Cyprus.

\section{Discussion}

The channelized sequences in coastal southwestern Cyprus were laid down in a fluvial braidplain environment. Channels are small and conglomerates within them generally grade up into the finer sediments, suggesting an initial high-energy pulse followed by waning flow. The mainly clast-supported nature of the conglomerates and their scoured bases suggest that they were deposited as bedload, rather than as mass-flow, deposits. Periodic high-energy events resulted in the deposition of immature conglomerates, while finer-grained, more mature sediments probably relate to waning flow. The paleosols and caliche horizons, as elsewhere, reflect relatively stable periods of local nondeposition.

The extensive, dominantly fine-grained sediments north of Kissonerga resemble floodplain sequences described from present-day semi-arid alluvial sequences in the southwestern U.S.A. (Blissenbach, 1954), and from the Devonian and New Red Sandstone of Scotland (Steel, 1974; Wilson, 1980). The presence of shallow but wide conglomerate channels suggest the presence of low-sinuosity, ephemeral streams (Leopold and Miller, 1956). The deposition of extensive silts, with conglomerate stringers, is suggestive of deposition as overbank sediments. The roots and caliche horizons suggest periods free of substantial flooding. The presence of thick floodplain sequences indicate periodic flood activity and regional channel stability during times of semi-arid conditions (Wilson, 1980). 


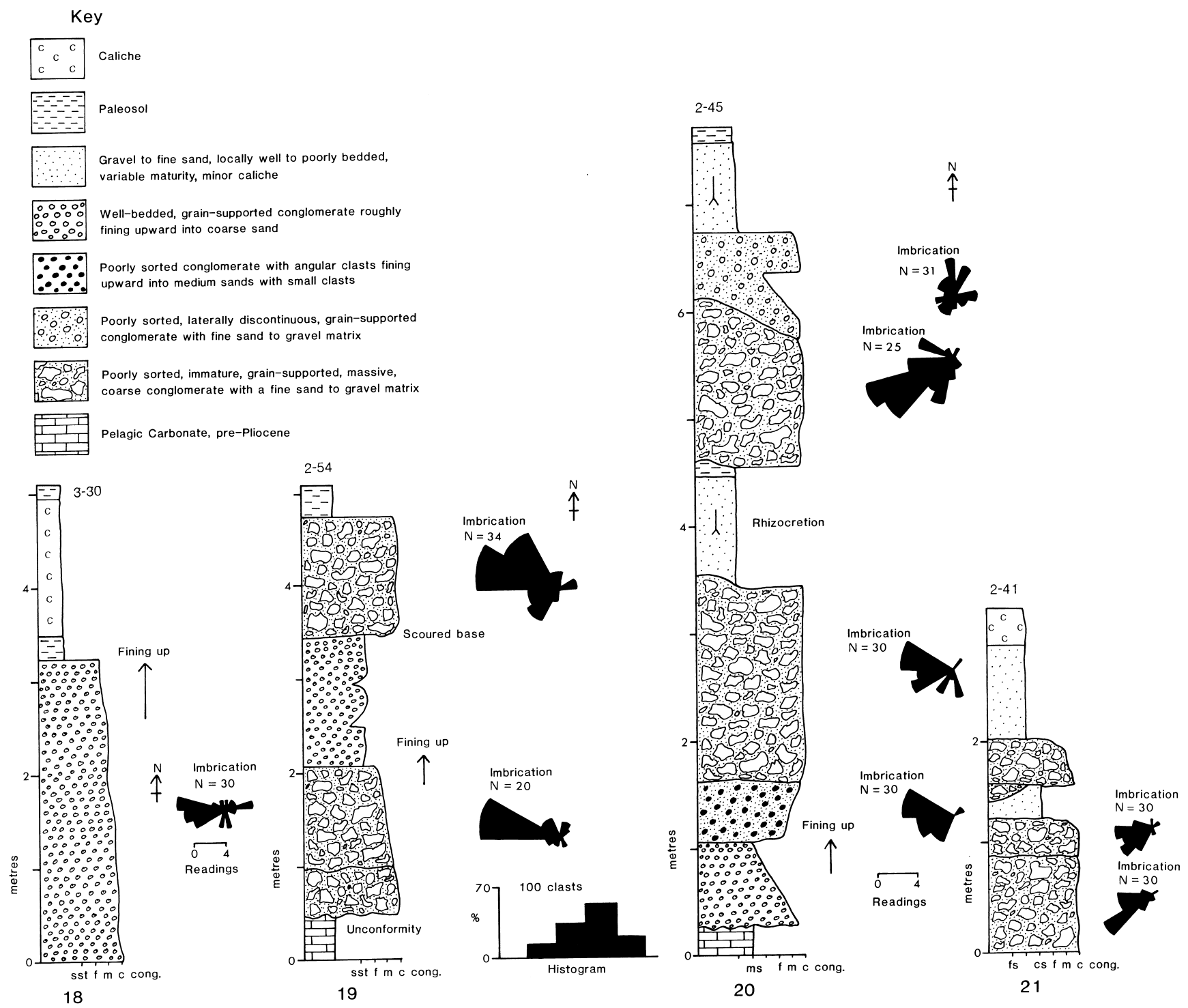

Figure 20. Logs of fanglomerate unit successions in southwestern Cyprus, (Log 18, F1 unit), Pissouri; (Log 19), Kouklia; (Log 20, F2), Akhelia; (Log 21,F2), Paphos area. See Figure 2 and Table 2 for locations of logs 18-21.

\section{Northwestern Area}

In general, in northwestern Cyprus, the F2-F4 Fanglomerate units crop out at successively lower topographical levels, as elsewhere in southern Cyprus. The F1 and F2 Fanglomerate units resemble exposures elsewhere (e.g., east of Paphos). The F3 Fanglomerate unit is generally restricted to areas close to present-day river courses, while the F4 Fanglomerate unit crops out within several meters of presentday channels. The F1-F3 Fanglomerate units consist of coarse, massive, unsorted, channelized conglomerates, passing up into sands and silts, capped by caliche and paleosol horizons. The sequences are generally red or gray. Channels are commonly cut into earlier conglomerates and paleosols and are generally $3-5 \mathrm{~m}$ wide and $70 \mathrm{~cm}$ deep.

In addition, the Fanglomerate Group was deposited within the Polis Graben. However, most of these deposits were eroded in Holocene to present-day time, and for this reason will not be discussed here (Payne, 1996; Payne and Robertson, 1995). However, toward the north of the graben, Fanglomerate Group sediments unconformably overlie late Pliocene? marine deltaic sediments in the Limni area. The
Fanglomerate Group is also well exposed in an isolated area near Kato Pyrgos on the northwest flank of the Troodos ophiolite. Borehole data reveal about $60 \mathrm{~m}$ of conglomerates, sands and silts, unconformably overlying lava and diabase of the Troodos ophiolite. Exposed sections can be correlated using local geomorphologic features (e.g., paleo-cliff lines). Exposed sequences of the F2 and F3 Fanglomerate units are similar to those seen on the north Troodos margin. The matrix within the Fanglomerate units consists of fine brown silts and sands. The clasts of the conglomeratic units are solely Troodos-derived (i.e., sand and diabase). Diabase clasts tend to be more mature than lava clasts, which were derived from more local sources. Limited clast imbrication data from Kato Pyrgos show a south-tonorth paleocurrent pattern, consistent with the overall dispersal away from the core of the Troodos Massif.

\section{Fanglomerate Units of the Kyrenia Range}

Sediments of the Fanglomerate Group crop out both to the north and south of the Kyrenia Range in northern Cyprus (Moore, 1960; Ducloz, 1968, 1972; Baroz, 1979). Coarse gravels, boulder beds and 


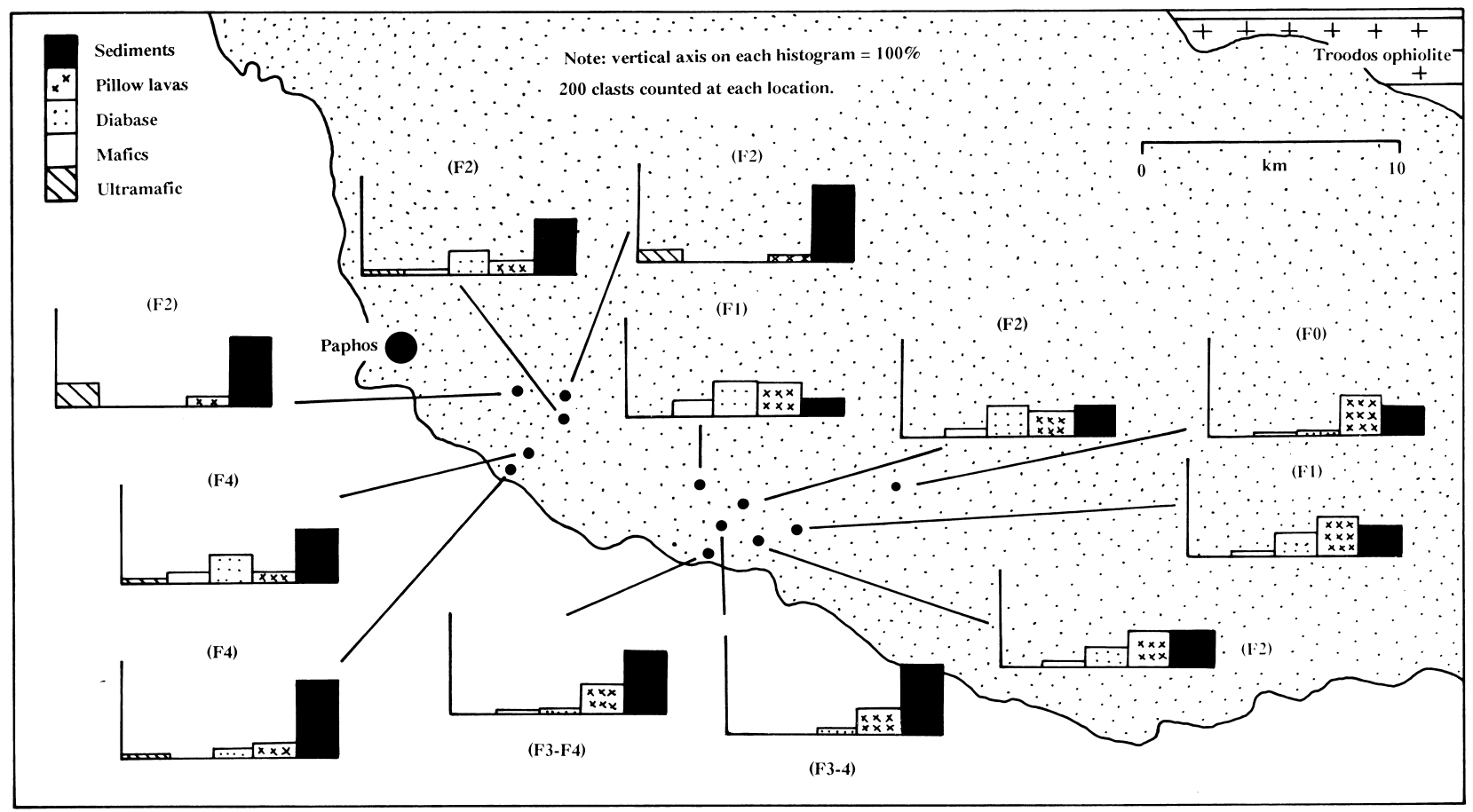

Figure 21. Clast analysis data from the Fanglomerate Group in southwestern Cyprus. The "F" number refers to the fanglomerate unit from which the clasts were sampled.

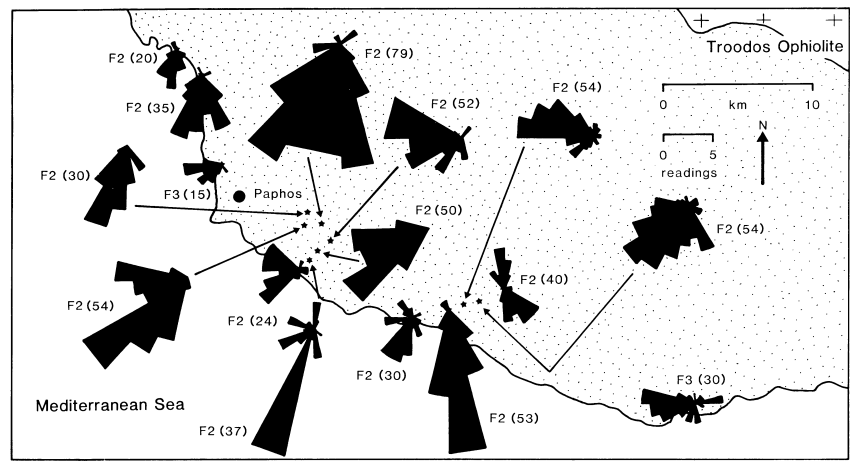

Figure 22. Rose diagrams showing paleocurrent data from southwestern Cyprus. The "F" number refers to the age of the fanglomerate unit. The number of measurements is shown in parentheses; see text for explanation.

immature conglomerates dominate, made up of angular to subangular, poorly sorted clasts. Local well-bedded chalky silts of lacustrine origin are capped by white soils differing from those seen on the north Troodos margin. Clasts in the Fanglomerate Group on the flanks of the Kyrenia Range mainly consist of limestone, chalk, rhyolite sandstone, graywacke, and conglomerate (Moore, 1960), lithologies that are restricted to the Kyrenia Range and do not crop out elsewhere on the island.

\section{REGIONAL COMPARISONS}

Comparison with Crete is pertinent as the regional setting above a northward-dipping subduction zone is similar to that of Cyprus (Fig. 1, inset). Also, the history of on-land Pleistocene sedimentation in Crete is relevant to the position of the deep-sea sediments drilled on the Mediterranean Ridge south of Crete at Sites 969, 970, 971 (Emeis, Robertson, Richter, et al., 1996) and can also be compared with other Mediterranean areas (Fairbridge, 1972).
In the Cretan area, northward subduction probably began around late Oligocene time (Kastens et al., 1992). Strong uplift of southern Crete then took place mainly in the late Miocene-Pliocene, coeval with crustal extension and opening of the Sea of Crete to the north (Meulenkamp et al., 1988; Postma et al., 1993; Postma and Drinia, 1993). Following the Messinian salinity crisis, marine transgression took place in Crete early in the Pliocene as in Cyprus, coupled with continued crustal extension. Pliocene marine terraces in eastern Crete are up to $450 \mathrm{~m}$ above sea level (Peters et al., 1985). Nemec and Postma (1993) relate these terraces to a Pliocene sea level highstand (to around $450 \mathrm{~m}$ ). An early Pleistocene coastal paleocliff is about $15 \mathrm{~m}$ above present-day sea level and later Pleistocene coastal fan-delta deposits are about $10 \mathrm{~m}$ above present-day sea level. Holocene paleobeaches and radiometrically dated wave-cut notches indicate continuing uplift and tilting, although the actual character and magnitude of relative sea-level change remains poorly constrained.

Early Pleistocene alluvial fans on Crete form relatively small coalescent cones mainly composed of unsorted angular debris derived by seaward erosion of the mountain front. Later fans are larger and are mainly stream-flow deposits dominated by better sorted gravels. High stream flow is interpreted to relate to melting of mountain ice. During the Holocene, earlier fans were dissected, associated with deposition of small gravel lobes (Postma and Nemec, 1990). The Pleistocene conglomerates in both Cyprus and Crete are similar in that both related to erosion of rapidly rising islands. However, in detail, the extreme local changes in relief, fault control, and strong influences of glaciation in Crete, all differ from the Fanglomerate Group in Cyprus.

Coarse alluvial deposition is also seen in many other mountainous Mediterranean areas, for example, the north coast of Euboea (Evvia), where resistant rocks, mainly Mesozoic carbonates, rise steeply to $>1500 \mathrm{~m}$ within several kilometers of the coast. High-energy fluvial deposits there have formed a series of steep-sided valleys, influenced by the effects of continued surface uplift (Lewin et al., 1992).

In the Antalya area of southwestern Turkey, compression and thrusting in the Late Miocene (Aksu phase) was followed by a switch to crustal extension and marine basin formation in the latest Miocene- 
early Pliocene (Glover, 1995). This basin was later infilled by marine silts and muds, followed by overall regression after the middle Pliocene. Progressive infilling by a prograding fluvial-deltaic complex from the Late Pliocene onward took place within an actively rifting basin, bounded by uplifting areas of the adjacent Tauride Mountains. Pleistocene and Holocene fan delta sequences were also documented from the Burdur basin further north (Kazanc, 1990). Again, this situation differs markedly from the deposition of the Fanglomerate Group in Cyprus.

The above comparisons emphasize that the high-relief type alluvial fans of southern Crete, Evvia, and Antalya (Nemec, 1990) are dissimilar to the Pleistocene Fanglomerate Group of southern Cyprus, although similarities exist with the coeval fans bordering the steep-sided Kyrenia Range. The alluvial fans of the coastal Southern Antalya area reflect the existence of a huge uplifted hinterland. By contrast, the southern Cyprus Fanglomerate Group deposition relates to the unusual situation of radial dispersal from a broad rising domeshaped area of only moderate relief (as today) and without local fault control, except locally in the Polis Graben.

\section{CONTROLS OF PLEISTOCENE CLASTIC DEPOSITION}

Deposition of the Pleistocene Fanglomerate Group was controlled by a number of variables including absolute tectonic uplift, isostasy, glacio-eustatic sea-level change, climatic change, nature of source rocks and autocyclic (naturally occurring) processes such as river capture or switches in fan-delta distributaries.

Tectonically controlled surface uplift, focused on Mt. Olympos, was clearly the dominant control on Fanglomerate Group deposition. Regional tectonic uplift during the latest Pliocene-Pleistocene, including the Kyrenia Range, is attributed to incipient continental collision of the African and Eurasian plates, specifically the underthrusting of the Eratosthenes Seamount beneath southern Cyprus. However, surface uplift was focused on Mt. Olympos by the effects of diapiric protrusion of serpentinite to form the dome-shaped Troodos Massif (Gass and Masson-Smith, 1963; Moores and Vine, 1971). Upward movement of serpentinite is seen as having been triggered by collision of the Eratosthenes Seamount with the Cyprus active margin (Robertson et al., 1995a, b).

Glacio-eustatic sea-level change is known to cause a change in gradient resulting in incision, and the development of a terraced floodplain (Leeder, 1993). Low-sinuosity channels, as inferred for the Fanglomerate Group in southern Cyprus, are particularly susceptible to the effects of gradient change (Schumm et al., 1988).

Short-term climatic change, especially the amount and distribution of rainfall, influences erosion and sediment supply, as inferred for the development of alluvial fans in the Dead Sea area (Frostick and Reid, 1989; Bowman, 1990) and in Oman (Maizels, 1987). The presence of late Pliocene-early Pleistocene lacustrine deposits and travertine in the Kyrenia Range suggests that the climate was then dominantly more humid than at present (Ducloz, 1972; Dreghorn, 1978). The existence of a climatic change between the Pliocene and Pleistocene is supported by evidence from the study of the sapropels (thin organic-rich layers) cored in the eastern Mediterranean Sea, including those on the Eratosthenes Seamount, south of Cyprus during ODP Leg 160. Sapropels are abundant in the Pliocene but diminish in the Pleistocene (Emeis, Robertson, Richter, et al., 1996). This decrease could, in part, be a result of a switch to a dominantly less humid climate after the Pliocene.

The sapropels appear to correspond to interglacial periods of high freshwater runoff creating a cap of low-salinity surface waters, leading to stratification of the water column and anoxia at depth (Emeis and Sakomoto, Chap. 3, this volume; Kroon et al., Chap. 14, this volume). This suggests that accumulation of the Fanglomerate Group was accompanied by marked changes in humidity and with periods significantly wetter than today. Erosion was also influenced by downcutting into lower units of the Troodos Massif. For example, relatively friable pillow lavas were eroded more readily than underlying compact, tough sheeted dykes. Also, the pelagic carbonates of the lower Tertiary sedimentary cover were more easily eroded than the late Miocene limestones, which are much more resistant. Diabase and limestone are thus significantly over-represented as clasts in the Fanglomerate Group, and extrusives under represented.

\section{Model for Pleistocene Clastic Deposition}

Any interpretation is unconstrained by dating of the F1 and F2 (early-middle Pleistocene) Fanglomerate units, while the F3 and F4 units are relatively well constrained by association with dated marine terraces (Poole et al., 1990; Poole and Robertson, 1992).

The Troodos Massif underwent partial uplift and emergence prior to the late Pliocene (Robertson, 1977; McCallum and Robertson, 1990; Robertson et al., 1991). However, intense tectonic uplift began in the late Pliocene marked, in southern Cyprus, by a sudden switch from quiet open-marine Pliocene muds and silts, to alluvial conglomerates and sands of the F1 unit (McCallum, 1989; Poole, 1992), with localized incision and channel downcutting (Houghton et al., 1990). Coeval tectonic uplift along the north Troodos margin gave rise to a fan-delta system, the Kakkaristra Formation (McCallum, 1989; McCallum and Robertson, 1995a) and final regression of the Mesaoria Sea between the Troodos Massif and the Kyrenia Range (McCallum and Robertson, 1995b). Uplift of southern Cyprus in the late Pliocene-Pleistocene is mirrored by subsidence and collapse of the Eratosthenes Seamount, as documented by ODP Leg 160 (Emeis, Robertson, Richter, et al., 1996; Robertson et al., 1995b; Fig. 23).

During the early-middle Pleistocene, the F1 Fanglomerate unit was shed from the rapidly rising Troodos Massif, centered on Mt. Olympos. To the north of Troodos steep-sided valleys were cut into the rising Mt. Olympos area by such agents as the Karyotis River, and alluvial conglomerate, gravel, and sand were deposited on overlying mainly late Pliocene sedimentary units: the Kakkaristra and Athalassa Formations. Alluvium was transported downslope through steepsided valleys cut into the Troodos Massif to form a laterally extensive low-relief braidplain (Fig. 24), that merged northward with distal alluvial material shed from the Kyrenia Range to the north. Troodosderived alluvium was transported both northwestward into Morphou Bay, but southeastward into Larnaca Bay. In southern and southwestern Cyprus respectively, fluvial architecture was influenced by local structures notably the Limassol Forest Block, southern Cyprus and the Polis Graben. Much of the alluvial material was shed south of Troodos and was transported offshore through a small number of preexisting large channels (Kouris river valley, south Cyprus; McCallum et al., 1993). Outbuilding of the F1 Fanglomerate probably took place during a sea-level high and was perhaps aided by erosion in a more humid climate than at present, judging by paleoclimatic evidence such as lacustrine deposits and travertine from the Kyrenia Range (Ducloz, 1968; Dreghorn, 1978).

The most probable cause of later development of the F2 Fanglomerate unit at a lower topographic level than the F1 unit is glacioeustatically controlled incision that took place during a time of continuing surface tectonic uplift. This caused initial downcutting and was followed by deposition during a subsequent sea-level rise. An alternative is that topographic gradients, and thus erosion and downcutting, were increased solely in response to a pulse of accelerated tectonic uplift. Another is that increased humidity accentuated run-off. In our favored glacio-eustatically controlled interpretation, sea level fell resulting in downcutting and was followed by a sea-level rise when the F2 unit formed, together with correlative littoral marine terraces in coastal areas (e.g., in southwestern Cyprus; Poole and Robertson, 1991). Terraces were created by subsequent downcutting.

The dominant control of the F3 and F4 Fanglomerates is inferred to be glacio-eustatic sea-level change during a time of continuing surface tectonic uplift. The F3 Fanglomerate Group unit is correlated with littoral marine terraces in southwestern, southern, and southeast- 
Figure 23. Sketch to show the relationship between the uplift of the Troodos massif and the collision of the Eratosthenes Seamount. The collision triggered the uplift and related serpentinite diapirism, followed by erosion and the deposition of the Pleistocene clastic sediment discussed in this paper.

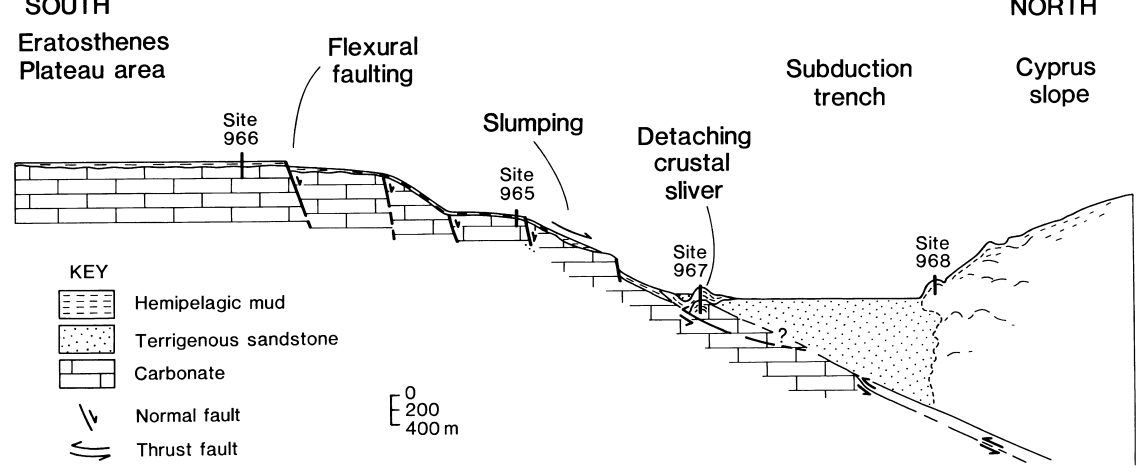

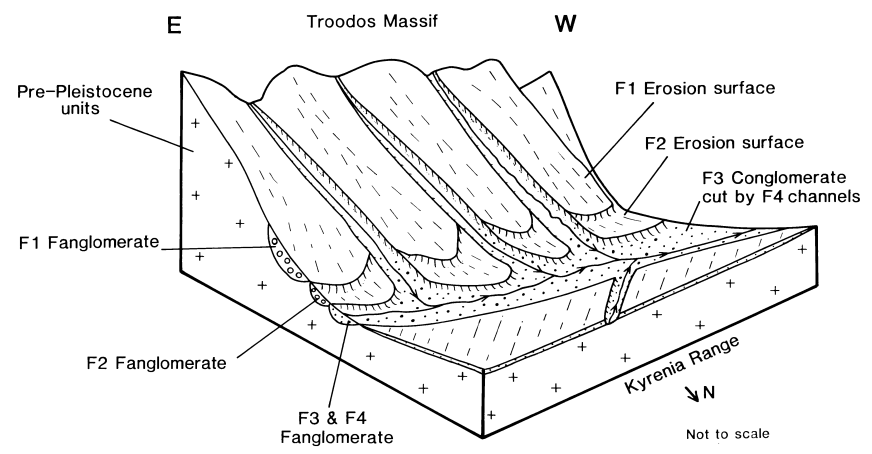

Figure 24. Block diagram showing the depositional relationships of F1-F4 fanglomerate units on the north Troodos margin.

ern Cyprus, dated at about 185-219 ka, and associated with the marine highstand that correlates with oxygen isotope substance $7 \mathrm{e}$ (Poole, 1992). Sea-level fall again stimulated incision, increasing downcutting and coarse sediment supply, followed by alluvial terrace formation during sea-level highs. Similar processes operated during genesis of the F4 marine terrace (at about 116-141 ka; i.e., oxygen isotope Substage 5e) and the associated F4 alluvial deposits. Climate change probably continued to play a related modifying role. Finally, an additional factor in the development of Holocene to present-day alluvial deposition is deforestation such as that in the Visiliks valley (Gomez, 1987).

A probable cause of the vast decrease in coarse sediment dispersal after the early-middle Pleistocene in the F2 unit is that the overall rate of surface tectonic uplift decreased after this time (Poole and Robertson, 1991). Alternatively, the absolute rate of tectonic uplift remained constant throughout Fanglomerate Group deposition (or even increased), but coarse sediment dispersal greatly decreased after early-middle Pleistocene in response to decreased erosion brought about by increasing aridity, channelization, and sediment by-passing. However, it seems unlikely that climatic change alone can explain the enormous decrease in the volume of clastic sediment after F2 times (middle-late Pleistocene), and a decrease in the rate of surface uplift is seen as the dominant control.

\section{CONCLUSIONS}

The coarse alluvial clastic sediments of the Fanglomerate Group of Cyprus record tectonic uplift and unroofing of the Troodos ophiolitic massif and its sedimentary cover during the Pleistocene-Holocene time. The Fanglomerate Group represents an unusual case of coarse sediment dispersal away from a focused point of uplift (i.e.,
Mt. Olympos), in contrast to the more usual and better known dispersal from elongate mountain fronts, or within half-grabens.

The pattern of sedimentation preserved around the periphery of the Troodos Massif reveals an overall radial, proximal to distal, relationship, with evidence for the development of alluvial fans, channel fans, braidplain and floodplain settings. The dominant source of clastic sediment was the Troodos ophiolite, particularly the erosionally resistant sheeted diabase dykes of the Troodos ophiolite. The Tertiary, mainly pelagic carbonate, succession overlying the Troodos Massif is less represented, as it was more easily disaggregated to form fine-grained particles. An exception is Miocene reef-related limestone, which is locally over-represented in the Fanglomerate Group. Clast provenance studies document unroofing of the Troodos Massif, and show that ultramafic rocks were already exposed in the Troodos core in early Pleistocene time. Borehole and outcrop evidence indicate that there was no major change in provenance during the Pleistocene. Paleocurrent data also indicate that sediment supply was focused in the same area near Mt. Olympos throughout the Pleistocene. The paleocurrent pattern is broadly radial, although with local variations, for example, related to the Polis Graben in western Cyprus and the Limassol Forest area of southern Cyprus. Paleocurrents were also influenced by channelization and the development of coastal alluvial plains (i.e., in southern Cyprus).

We infer that the dominant factor in the early- to middle Pleistocene Fanglomerate (i.e., F1 unit) was a high rate of surface tectonic uplift, in turn controlled by the effect of regional tectonic uplift, serpentinite diapirism and isostasy. The early-middle Pleistocene Fanglomerate F2 unit probably relates to deposition during a glacioeustatic sea-level high, followed by continuing of surface uplift. The late Pleistocene (F3 and F4 units) are correlated with littoral marine terraces, dated at about 184-219 ka and 116-141 ka, respectively, and support deposition during marine highstands, followed by further uplift and downcutting. Additional controls on deposition include the probability that climate was periodically more humid during interglacials, with increased erosion and sediment supply. Anthropogenic effects appear in the Holocene, notably deforestation. Overall, the greatly decreased volume of clastic sedimentation after the earlymiddle Pleistocene suggests that tectonic uplift climaxed, then waned during the late Pleistocene to the present day.

\section{ACKNOWLEDGMENTS}

Andrew Poole acknowledges an NERC Research Studentship at the University of Edinburgh, while Alastair Robertson thanks Edinburgh University for its support. Mrs. D. Baty assisted with drafting and Mrs. Y. Cooper with photographs. We wish to acknowledge field support by the Geological Survey Department of Cyprus. The manuscript benefited from comments by Jean McCallum, Basil Gomez, and Costas Xenophontos. 


\section{REFERENCES}

Bagnall, P.S., 1960. The Geology and Mineral Resources of the Pano Lefkara-Larnaca Area. Mem. Cyprus Geol. Surv. Dep., 5.

Baroz, F., 1979. Etude géologique dans le Pentadaktylos et la Mesaoria (Chypre septentrionale) [Thèse Doctorat d'Etat]. Univ. Nancy.

Bear, L.M., 1960. The Geology and Mineral Resources of the Akaki-Lythrondondha Area. Mem. Cyprus Geol. Surv. Dep., 3.

Bear, L.M., and Morel, S.W., 1960. The Geology and Mineral Resources of the Agros-Akrotiri area. Mem. Cyprus Geol. Surv. Dep., 7.

Bellamy, C.V., and Jukes-Browne, A.J., 1905. The Geology of Cyprus: Plymouth (W. Brendon and Son).

Blissenbach, E., 1954. Geology of alluvial fans in semi-arid regions. Geol. Soc. Am. Bull., 65:175-190.

Boggs, S., Jr., 1969. Relationship of size and composition in pebble counts. J. Sediment. Petrol., 39:1243-1247.

Bowman, D., 1990. Climatically triggered Gilbert-type lacustrine fan deltas, the Dead Sea area, Israel. In Colella, A., and Prior, D.B. (Eds.), CoarseGrained Deltas. Spec. Publ. Int. Assoc. Sedimentol., 10:273-280.

Carr, J.M., and Bear, L.M., 1960. The Geology and Mineral Resources of the Peristerona-Lagoudhera Area. Mem. Cyprus Geol. Surv. Dep., 2.

Collier, R.F.L., Leeder, M.R., and Jackson, J.A., 1993. Quaternary drainage development, sediment fluxes and extensional tectonics in Greece. In Lewin, J., Macklin, M.G., and Woodward, J.C. (Eds.), Mediterranean Quaternary River Environments. Proc. Int. Conf. Univ. Cambridge, U.K., 18-29th Sept., 1992.

Cowper-Reed, F.R., 1930. Contributions to the geology of Cyprus. Geol. Mag., 67:241-271.

Dreghorn, W., 1978. Landforms of the Girne Range, Northern Cyprus. Miner. Res. Explor. Inst. (MTA) of Turkey, 172.

Ducloz, C., 1965. Revision of the Pliocene and Quaternary Stratigraphy of the Central Mesaoria. Ann. Rep. Cyprus Geol. Surv. Dep., 1964:31-42.

, 1968. Les formations quaternaires de la région de Klepini (Chypre) et leur place dans la chronologie du Quaternaire méditerranéan. Arch. Sci., Genève, 20

, 1972. The geology of the Bellapais-Kythrea area of the central Kyrenia Range, Cyprus. Cyrpus Geol. Surv. Dept. Bull., 6:75.

Eaton, S., 1987. The sedimentology of Mid-Late Miocene carbonates and evaporites in southern Cyprus [Ph.D. thesis]. Univ. of Edinburgh.

Eaton, S., and Robertson, A.H.F., 1993. The Miocene Pakhna Formation, Cyprus, and its relationship to the Neogene tectonic evolution of the Eastern Mediterranean. Sediment. Geol., 86:273-296.

Emeis, K.-C., Robertson, A.H.F., Richter, C., et al., 1996. Proc. ODP, Init. Repts., 160: College Station, TX (Ocean Drilling Program).

England, P.C., and Molnar, P., 1993. Surface uplift, uplift of rocks, and exhumation of rocks. Geology, 18:1173-1177.

Fairbridge, R.W., 1972. Quaternary sedimentation in the Mediterranean region controlled by tectonics, paleoclimates and sea-level. In Stanley, D.J. (Ed.), The Mediterranean Sea: Stroudsburg, PA (Dowden, Hutchison and Ross), 99-113.

Follows, E.J., 1990. Sedimentology and tectonic setting of Miocene reef and related sediments in Cyprus [Ph.D. thesis]. Univ. Edinburgh.

Follows, E.J., Robertson, A.H.F., and Scoffin, T.P., 1996. Tectonic controls of Miocene reefs and related carbonate facies in Cyprus. In Fransen, E.K., Esteban, M., Ward, W.C., and Rouchy, J.-M. (Eds.), Models for Carbonate Stratigraphy from Miocene Reef Complexes of Mediterranean Regions. SFCM Concepts Sedimentol. Paleontol., 5:317-332.

Frostick, L.E., and Reid, I., 1989. Climatic versus tectonic controls on fan sequences; lessons from the Dead Sea, Israel. J. Geol. Soc. London, 146:527-539

Gass, I.G., 1960. The Geology and Mineral Resources of the Dhali Area. Mem. Cyprus Geol. Surv. Dep., 4.

Gass, I.G., and Masson-Smith, D., 1963. The geology and gravity anomalies of the Troodos Massif, Cyprus. Phil. Trans. R. Soc. London A, 255:417467.

Gifford, J.A., 1978. Paleogeography of archaeological sites of the Larnaca lowlands, southeastern Cyprus [Ph.D. thesis]. Univ. Minnesota.

Glover, C. P., 1995. Plio-Quaternary sediments and neotectonics of the Isparta Angle, S.W. Turkey [Ph.D. thesis] Univ. Edinburgh.

Gomez, B., 1987. The alluvial terraces and fills of the Lower Vasilikos Valley, in the vicinity of Kalavasos, Cyprus. Trans. Inst. Brit. Geographers, 12:345-359.

Harvey, A.M., 1984. Debris flows and fluvial deposits in Spanish Quaternary alluvial fans: implications for fan morphology. In Koster, E.H., and Steel,
R.J. (Eds.), Sedimentology of Gravels and Conglomerates. Mem.-Can. Soc. Pet. Geol., 10:123-132.

Harvey, A.M., and Wells, S.G., 1987. Response of Quaternary fluvial systems to differential epeirogenic uplift: Aguas and Feos river systems, southeast Spain. Geology, 15:689-693.

Hein, F.J., and Walker, R.G., 1977. Bar evolution and development of stratification in the gravelly braided Kicking Horse River, British Columbia. Can. J. Earth Sci., 14:562-570.

Henson, F.R.S., Browne, R.V., and McGinty, J., 1949. A synopsis of the stratigraphy and geological history of Cyprus. Q. J. Geol. Soc. London, 105:1-41.

Heward, A.P., 1978. Alluvial fans and lacustrine sediments from the Stephanian A and B (La Magdalena, Cinera-Matallina and Sabero) coalfields, northern Spain. Sedimentology, 25:251-488.

Houghton, S.D., Jenkins, D.G., Xenophontos, C., and Gass, I.G., 1990 Microfossil evidence for a latest Pliocene ages for Amathus and Khirokitia channel deposits, southern Cyprus, and thereby the unroofing of the Troodos Massif. In Malpas, J., Moores, E.M., Panayiotou, A., and Xenophontos, C. (Eds.), Ophiolites: Oceanic Crustal Analogues: Nicosia, Cyprus (Geol. Surv. Dep., Minist. Agric. Nat. Resour.), 231-234.

Kastens, K.A., Breen, N.A., and Cita, M.B., 1992. Progressive deformation on an evaporite-bearing accretionary complex: SeaMARC 1, SeaBeam, and piston-core observations from the Mediterranean Ridge. Mar. Geophys. Res., 14:249-298.

Kazanc, N., 1990. Fan-delta sequence in the Pleistocene and Holocene Burdur Basins, Turkey: the role of basin-margin configuration in sediment entrapment and differential facies development. In Colella, A., and Prior, D.B. (Eds.), Coarse-Grained deltas. Spec. Publ. Int. Assoc. Sedimentol., 10:185-198.

Kraus, M.J., 1984. Sedimentology and tectonic setting of early Tertiary quartzite conglomerates, north west Wyoming. In Koster, E.H., and Steel, R.J. (Eds.), Sedimentology of Gravels and Conglomerates. Mem.-Can. Soc. Pet. Geol., 10:203-216.

Leeder, M.R., 1993. Tectonic controls upon drainage basin development, river channel migration and alluvial architecture: implications for hydrocarbon reservoir development and characteristics. In North, C.P., and Prosser, D.J. (Eds.), Characterisation of Fluvial and Aeolian Reservoirs. Geol. Soc. Spec. Publ. London, 73:7-22.

Leopold, L.B., and Miller, J.R., 1956. Ephemeral streams - hydraulic factors and their relation to the drainage net. Geol. Surv. Prof. Pap. U.S., 282B:39-85.

Lewin, J., Macklin, M.G., and Stiros, S., 1992. River development in active tectonic, high relief environments: north Central Euboia, Greece. Mediterranean Quaternary River Environments. Int. Symp., Univ. of Cambridge, U.K., 28-29 September 1992. (Abstract)

Lewis, D.W., Laird, M.G., and Powell, R.D., 1980. Debris flow deposits of early Miocene age, Deadman Stream, Marlborough. Sediment. Geol., 27:83-118.

Limonov, A.F., Woodside, J.M., and Ivanov, M.K. (Eds.), 1994. Mud Volcanism in the Mediterranean and Black Seas and Shallow Structure of the Eratosthenes Seamount. Initial Results of the Geological and Geophysical Investigations during the Third "Training-through-Research" Cruise of the R/V Gelendzhik (June-July 1993). UNESCO Rep. Mar. Sci., 64.

Maizels, J.K., 1987. Plio-Pleistocene raised channel systems of western Sharqiya (Wahiba), Oman. In Frostick, L., and Reid, I. (Eds.), Desert Sediments: Ancient and Modern. Geol. Soc. Spec. Publ. London, 35:3150

McCallum, J.E., 1989. Sedimentation and tectonics of the Plio-Pleistocene of Cyprus [Ph.D. thesis]. Univ. of Edinburgh.

McCallum, J.E., and Robertson, A.H.F., 1990. Pulsed uplift of the Troodos Massif: evidence from the Plio-Pleistocene Mesaoria Basin. In Malpas, J., Moores, E.M., Panayiotou, A., and Xenophontos, C. (Eds.), Ophiolites: Oceanic Crustal Analogues. Proc. Symp. "Troodos 1987": Nicosia, Cyprus (Geol. Surv. Dep., Minist. Agric. Nat. Resour.), 217-229.

1995a. Sedimentology of two fan-delta systems in the PliocenePleistocene of the Mesaoria Basin, Cyprus. Sediment. Geol., 98:215-244. 1995b. Late Pleistocene-early Pleistocene Athalassa Formation, north-central Cyprus: carbonate sand bodies in a shallow seaway between two emerging landmasses. Terra Nova, 7:265-278.

McCallum, J.E., Scrutton, R.A., Robertson, A.H.F., and Ferrari, W., 1993. Seismostratigraphy and Neogene-Recent depositional history of the south central continental margin of Cyprus. Mar. Pet. Geol., 10:426-425.

Meulenkamp, J.E., Wortel, M.J.R., van Wamel, W.A., Spakman, W., and Hoogerduijn Strating, E., 1988. On the Hellenic subduction zone and the 
geodynamic evolution of Crete since the late middle Miocene. Tectonophysics, 146:203-215.

Miall, A.D., 1978. Lithofacies types and vertical profile models in braided river deposits: a summary. In Miall, A.D. (Ed.), Fluvial Sedimentology. Mem. Can. Soc. Pet. Geol., 5:597-604.

Moore, T.A., 1960. The Geology and Mineral Resources of the AstromeritisKormakiti Area. Mem. Cyprus Geol. Surv. Dep., 6.

Moores, E.M., and Vine, F.J., 1971. The Troodos Massif, Cyprus and other ophiolites as oceanic crust: evaluation and implications. Philos. Trans. $R$. Soc. London A, 268:443-466.

Muto, T., 1987. Coastal Fan processes controlled by sea-level changes: a Quaternary example from the Tenryugawa Fan System, Pacific coast of central Japan. J. Geol., 95:716-724.

Nemec, W., 1990. Aspects of sediment movement on steep delta slopes. In Colella, A., and Prior, D.B., (Eds.), Coarse-Grained Deltas. Spec. Publ. Int. Assoc. Sedimentol., 10:29-73.

Nemec, W., and Postma, G., 1993. Quaternary Alluvial Fans in Southwestern Crete: Sedimentation Processes and Geomorphic Evolution. Spec. Publ. Int. Assoc. Sedimentol., 17:235-276.

Nemec, W., and Steel, R.J., 1984. Alluvial and coastal conglomerates: their significant features and some comments on gravelly mass-flow deposits. In Koster, E.H., and Steel, R.J. (Eds.), Sedimentology of Gravels and Conglomerates. Mem. Can. Soc. Geol., 10:1-31.

, (Eds.), 1988. Fan Deltas: Sedimentology and Tectonic Settings: London (Blackie and Son).

Pantazis, T. M., 1967. The Geology and Mineral Resources of the Pharmakas-Kalavasos Area. Mem. Cyprus Geol. Surv. Dep., 8.

Payne, A.S., 1996. The structural and sedimentary evolution of the Polis graben system, West Cyprus [Ph.D. thesis]. Univ. Edinburgh.

Payne, A.S., and Robertson, A.H.F., 1995. Neogene supra-subduction zone extension in the Polis graben system, West Cyprus. J. Geol. Soc. London, 153:613-628.

Peters, J.M., Troelstra, S.R., and van Harten, D., 1985. Late Neogene and Quaternary vertical movements in eastern Crete and their regional significance. J. Geol. Soc. Lond., 142:501-513.

Poole, A.J., 1992. Sedimentology, neotectonics and geomorphology related to tectonic uplift and sea-level change: Quaternary of Cyprus [Ph.D. thesis]. Univ. Edinburgh.

Poole, A.J., and Robertson, A.H.F., 1991. Quaternary uplift and sea-level change at an active plate boundary, Cyprus. J. Geol. Soc. London, 148:909-921.

Poole, A.J., Shimmield, G.B., and Robertson, A.H.F., 1990. Late Quaternary uplift of the Troodos ophiolite, Cyprus: uranium series dating of Pleistocene coral. Geology, 18:894-897.

Postma, G., and Drinia, H., 1993. Architecture and sedimentary facies evolution of a marine, expanding outer-arc half-graben (Crete, Late Miocene). Basin Res., 5:103-124.

Postma, G., Fortuin, A.R., and Van Wamel, W.A., 1993. Basin-Fill Patterns Controlled by Tectonics and Climate: the Neogene "Fore-Arc" Basins of Eastern Crete as a Case History. Spec. Publ. Int. Assoc. Sedimentol., 20:335-362.

Postma, G., and Nemec, W., 1990. Regressive and transgressive sequences in a raised Holocene gravelly beach, Southwestern Crete. Sedimentology, 37:907-920.

Robertson, A.H.F., 1976. Pelagic chalks and calciturbidites from the lower Tertiary of the Troodos Massif, Cyprus. J. Sediment. Petrol., 46:1000710016.
, 1977. Tertiary uplift history of the Troodos Massif, Cyprus. Geol. Soc. Am. Bull., 88:1763-1772.

1990. Tectonic evolution of Cyprus. In Malpas, J., Moores, E.M., Panayiotou, A., and Xenophontos, C. (Eds.), Ophiolites: Oceanic Crustal Analogues. Proc. Symp. "Troodos 1987," Nicosia, Cyprus (Geol. Surv. Dep., Minist. Agric. Nat. Resour.), 235-250.

Robertson, A.H.F., Eaton, S., Follows, E.J., and McCallum, J.E., 1991. The role of local tectonics versus global sea-level change in the Neogene evolution of the Cyprus active margin. In Macdonald, D.I.M. (Ed.), Sedimentation, Tectonics and Eustacy Sea-level Changes at Active Margins. Spec. Publ. Int. Assoc. Sedimentol., 12:331-369.

Robertson, A.H.F., Emeis, K.-C., Richter, C., Blanc-Valleron, M.-M., Bouloubassi, I., Brumsack, H.-J., Cramp, A., De Lange, G.J., Di Stefano, E., Flecker, R., Frankel, E., Howell, M.W., Janecek, T.R., Jurado-Rodríguez, M.J., Kemp, A.E.S., Koizumi, I., Kopf, A., Major, C.O., Mart, Y., Pribnow, D.F.C., Rabaute, A., Roberts, A.P., Rullkötter, J.H., Sakamoto, T. Spezzaferri, S., Staerker, T.S., Stoner, J.S., Whiting, B.M., and Woodside, J.M., 1995a. Evidence of collisional processes associated with ophiolite obduction in the eastern Mediterranean: results from Ocean Drilling Program Leg 160. GSA Today, 5:213-221.

Robertson, A.H.F., Kidd, R.B., Ivanov, M.K., Limonov, A.F., Woodside, J.M., Galindo-Zaldivar, J., and Nieto, L., 1995b. Eratosthenes Seamount, easternmost Mediterranean: evidence of active collapse and underthrusting beneath the Cyprus active margin. Terra Nova, 7:254-264.

Schumm, S.A., Harvey, M.D., and Watson, C.C., 1988. Incised Channels: Morphology, Dynamics and Control: Littleton, CO (Water Resources Publications).

Steel, R.J., 1974. New Red Sandstone floodplain and piedmont sedimentation in the Hebridean Province, Scotland. J. Sediment. Petrol., 44:336357.

Stevens, R.L., and Wedel, P., 1992. Facies sequences in Quaternary alluvial deposits, S.E. Cyprus. Mediterranean Quaternary River Environments: an International Symp., Univ. of Cambridge, U.K., 28-29 September 1992. (Abstract)

Tucker, M.E., 1988. Techniques in Sedimentology: Oxford (Blackwell Scientific).

Varga, R.J., and Moores, E.M., 1985. Spreading structure of the Troodos ophiolite, Cyprus. Geology, 13:846-850.

Vita-Finzi, C., 1969. The Mediterranean Valleys: Geological Changes in Historical Times: Cambridge (Cambridge Univ. Press).

Wilson, A.C., 1980. The Devonian sedimentation and tectonism of a rapidly subsiding semi-arid fluvial basin in the Midland Valley of Scotland. Scott. J. Geol., 16:291-313.

Wilson, R.A.M., 1957. Progress report. In Ingham, F. (Ed.), Ann. Rep. 1956, Cyprus Geol. Surv. Dep., 23-27.

Zomenis, S.L., 1977. Hydrology of the central Mesaoria (Cyprus) [Ph.D. thesis]. Univ. London.

Date of initial receipt: 15 January 1997

Date of acceptance: 19 June 1997

Ms 160SR-064 